\title{
THE RADIATION FROM AND THE MELTING POINTS OF PALLADIUM AND PLATINUM.
}

\author{
By C. W. Waidner and G. K. Burgess.
}

\section{CONTENTS.}

Page.

I. INTRODUCTION ................................. . . . 63

High temperature scale; object of investigation.

II. STANDARDIZATION OF OPTICAI, PYROMETER..................

Experimental black-body; calibration of pyrometer lamps; monochromatic glasses; absorption factors of glass, mirrors, and sector disks; polarized light from platinum and palladium.

III. THE RADIATION FROM PLATINUM AND PALLADIUM..............

By furnace, melting point, and equal radiation methods; radiation from platinum in hydrogen; recomputation of previous results.

IV. MELTING POINTS OF PALLADIUM AND PLATINUM $\ldots \ldots \ldots \ldots \ldots \ldots$

By the black-body method.

By the surface radiation method.

By the thermoelectric method.

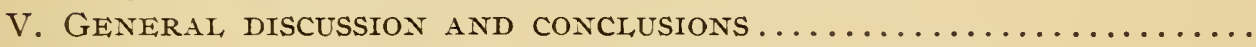

\section{INTRODUCTION.}

The scale to which all measurements of temperature, from the lowest attainable to $\mathrm{I} 200^{\circ} \mathrm{C}$, are now referred is that of the gas thermometer. A consideration of the best experimental data now available leads to the conclusion that the scale of the nitrogen gas thermometer, which is the standard above $200^{\circ}$, is probably in agreement with the absolute thermodynamic scale to within the limits of accuracy at present attainable in high temperature gas thermometry (above $500^{\circ}$ ). The present upper limit of the gas scale is about $\mathrm{I} 200^{\circ}$, i. e., where the limit of reasonably certain accuracy is $5^{\circ}$. With facilities that are now attainable this limit could perhaps be raised some $300^{\circ}$ or $400^{\circ}$ For the range of temperatures above $1500^{\circ}$ the scale $1111 \mathrm{st}$ be based, for the present at least, on extrapolation by means of the radiation laws, which have some theoretical support, and can be tested within the range of the gas scale. 
In the practical establishment and use of the scale it is convenient to have certain easily reproducible fixed points. Two standard temperatures of reference that have been made the basis of numerous investigations are the melting points of palladium and platinum. The best determinations of these melting points have differed by some $70^{\circ}$ within the past two years, and the true values may still be regarded as uncertain by $40^{\circ}$.

In the present paper are described the results of experiments on the melting points of these metals, as determined by several different methods, and in particular the results obtained by the application of the Wein ${ }^{1}$ equation giving the relation between the absolute temperature of a black-body and the intensity of any monochromatic radiation.

The first part of the paper is devoted to a description of the calibration of the optical pyrometer and accessories used in the investigation, and includes a discussion of the practical realization of blackness in certain furnaces used as light sources. It was also found necessary to study in detail the effect, on the temperature measurments, of the lack of monochromatism in the glasses used with the pyrometer. The observations on the monochromatic radiation from palladium and platinum strips, which is next undertaken, using red, green, and blue light, give results in very close agreement when applied to the determination of melting points. These optical determinations also agree with the more exact optical measurments made on the melting points of the metals placed within an irridium tube furnace which approximates a black-body. The values of the melting points as determined by the usual thermoelectric method are some $45^{\circ}$ lower than those found by the two optical methods.

\section{STANDARDIZATION OF OPTICAL PYROMETER.}

The optical pyrometer 11sed in the present investigation is of the Holborn-Kurlbaum type ${ }^{2}$ in the form in which it was originally

${ }^{1}$ The Wien equation $J=c_{1} \lambda^{-5} e^{-\frac{c_{2}}{\lambda^{\prime} \mathrm{I}}}$ is a sufficiently close approximation to the more general equation of planck $J=c_{1} \lambda^{-5}\left(e^{+\frac{c_{2}}{\lambda^{\prime} \mathrm{T}}-1}\right)^{-1}$ within the visible spectrum and for any attainable temperature.

${ }^{2}$ Holborn and Kurlbaum, Bericlite Berlin Akad. d. Wiss., p. 712; 190I. Ann. d. Plyysik, 10, p. 225; 1903. 
constructed by Siemens and Halske, embodying the disappearing filament principle. ${ }^{3}$ The suitability of this instrument for temperature measurements, the order of accuracy attainable, and the constancy of the lamps have been discussed in a previous paper. ${ }^{4}$

Experimental Black-Body.-The only perfectly definite radiation independent of the physical properties of the radiator, and dependent only on the temperature, is the radiation of a Kirchhoff blackbody. In the absence of definite knowledge concerning the law of radiation for each particular substance, it is not possible at present to measure the true temperature on the thermodynamic scale by the intensity of the radiation of any such substance. It is only feasible at present to express very high temperatures on the black-body scale ${ }^{5}$ and it is therefore necessary for the realization of this scale, to construct a black-body that can be used experimentally for the calibration of optical pyrometers.

The black-body used in this work is a modified form of the electrically heated black-body devised by Lummer and Kurlbaum. ${ }^{6}$ The modification consists in the addition of supplementary heating coils, on independent electrical circuits, wound on a porcelain tube inclosing the black-body. These coils, which project $8 \mathrm{cms}$ beyond each end, are wound so as to give a very uniform temperature distribution throughout the black-body, a condition which can be realized with a few trials. The winding of these secondary coils is very close about the ends of the black-body and very open about the center.

The accompanying Table I will serve as an illustration of the uniformity of temperature obtainable throughout the interior of this compensated black-body. Temperatures were measured by an exploring thermocouple. The distance from the central diaphragm used as a radiating source to the opening is $19 \mathrm{cms}$.

${ }^{3}$ Morse, U. S. Letters Patent, 696878, 696916; rgo2.

${ }^{4}$ Waidner and Burgess, Optical Pyrometry, this bulletin, 1, p. I89; 1905.

${ }^{5}$ The black-body temperature, $s^{\circ}$, is the temperature at which the ideal black-body radiator of Kirchhoff would emit radiation of the same intensity as a substance at a temperature $t^{\circ}$ for the particular wave length under consideration. Black-body temperatures might conveniently be indicated by $t^{\circ} \mathrm{K}$ where ${ }^{\circ} \mathrm{K}$ means the Kirchhoff absolute scale. When it is necessary to specify the wave length, this could be done as follows $\left(t^{\circ} K_{\lambda}\right)$ : For example, the expression " $1000^{\circ} \mathrm{Abs}$. black-body temperature for wave length $0.650 \mu$," becomes $1000^{\circ} K_{0 \cdot 650}$ or $727^{\circ} K_{0 \cdot 650} \mathrm{C}$.

${ }^{6}$ Lummer and Kurlbaum, Verh. Deut. Phys. Ges., 17, p. I06; ISgS. Ann. d. Physik. 5, p. 829; I90I. 
TABLE I.

Temperature Distribution Within Black-Body.

\begin{tabular}{|c|c|c|c|c|c|c|}
\hline \multicolumn{2}{|c|}{$\begin{array}{c}\text { Distance in cm from central } \\
\text { diaphragms }\end{array}$} & \multirow{2}{*}{$\begin{array}{c}\circ \\
621^{\circ}\end{array}$} & \multirow{2}{*}{$\frac{2}{621^{\circ}}$} & \multirow{2}{*}{$\begin{array}{c}4 \\
620^{\circ}\end{array}$} & \multirow{2}{*}{$\begin{array}{c}8 \\
612\end{array}$} & \multirow{2}{*}{$\begin{array}{l}{ }^{12} \\
\ldots \ldots \ldots\end{array}$} \\
\hline \multirow{4}{*}{ Temperature } & Series I .... & & & & & \\
\hline & Series II ... & 1041 & 1042 & 1042 & 1032 & \\
\hline & Series III. & 1308 & 1310 & 1311 & 1300 & \\
\hline & Series IV. & 1244.9 & 1244.9 & 1244.7 & 1244.7 & 1244.8 \\
\hline
\end{tabular}

In order to determine the temperature of the radiating wall accurately, it is important that its front and back surfaces be at approximately the same temperature. Two thermocouples were therefore 11sed with the junctions in contact with these surfaces.

The ordinary form of black-body uniformly wound with platinum ribbon does not realize with the highest attainable accuracy the two necessary conditions for ideal black-body radiation, namely, miniform temperature distribution throughont the radiating inclosure and a determinable temperature of the radiating wall. This is illustrated in Fig. I, where $\mathrm{A}$ is such a black-body, ${ }^{7}$ provided with diaphragms both in front and back of the radiating wall. The plot immediately below A gives the temperature distribution as measured by thermocouples in the manner indicated. It will be seen that the temperature distribution is not nniform, and that the back and front of the radiating wall differ considerably in temperature.

If the diaphragums back of the radiating wall are removed, as in $\mathrm{B}$, the temperature distribution in front of the radiating wall nay be improved, but the actual temperature of the radiating wall itself is impossible of exact determination. The temperature distribution in the ordinary black-body (A of Fig. I) can be improved without the use of supplementary lieating coils, by winding it with a platinn1m ribbon cut so that its width diminishes as the ends are approached.

After the calibration of the pyrometer lamps in terms of the radiation of the nearly ideal black-body described above, they were applied to an investigation of the degree of approximation to blackness of various forms of electrically heated furnaces. Measurements

\footnotetext{
The black-horly radiator alone is shown in the illustration. In use this was surrounded by concentric porcelain tubes.
} 
up to $\mathrm{I} 300^{\circ}$ made on ordinary Heraeus resistance furnaces, in which the porcelain heating tube $(2 \mathrm{~cm}$ diam.; length of winding equals 25 diameters) is uniformly wound with platinnun ribbon, gives an approximation to black-body radiation to within $5^{\circ}$, for a radiating surface at the center of the furnace. Experiments with the interior of the furnaces, both coated with black oxides and uncoated, gave no certain difference. When thermocouples are used in furnaces coated with metallic oxides, which conduct at lower temperatures than porcelain, care must be take to avoid leakage from the heating
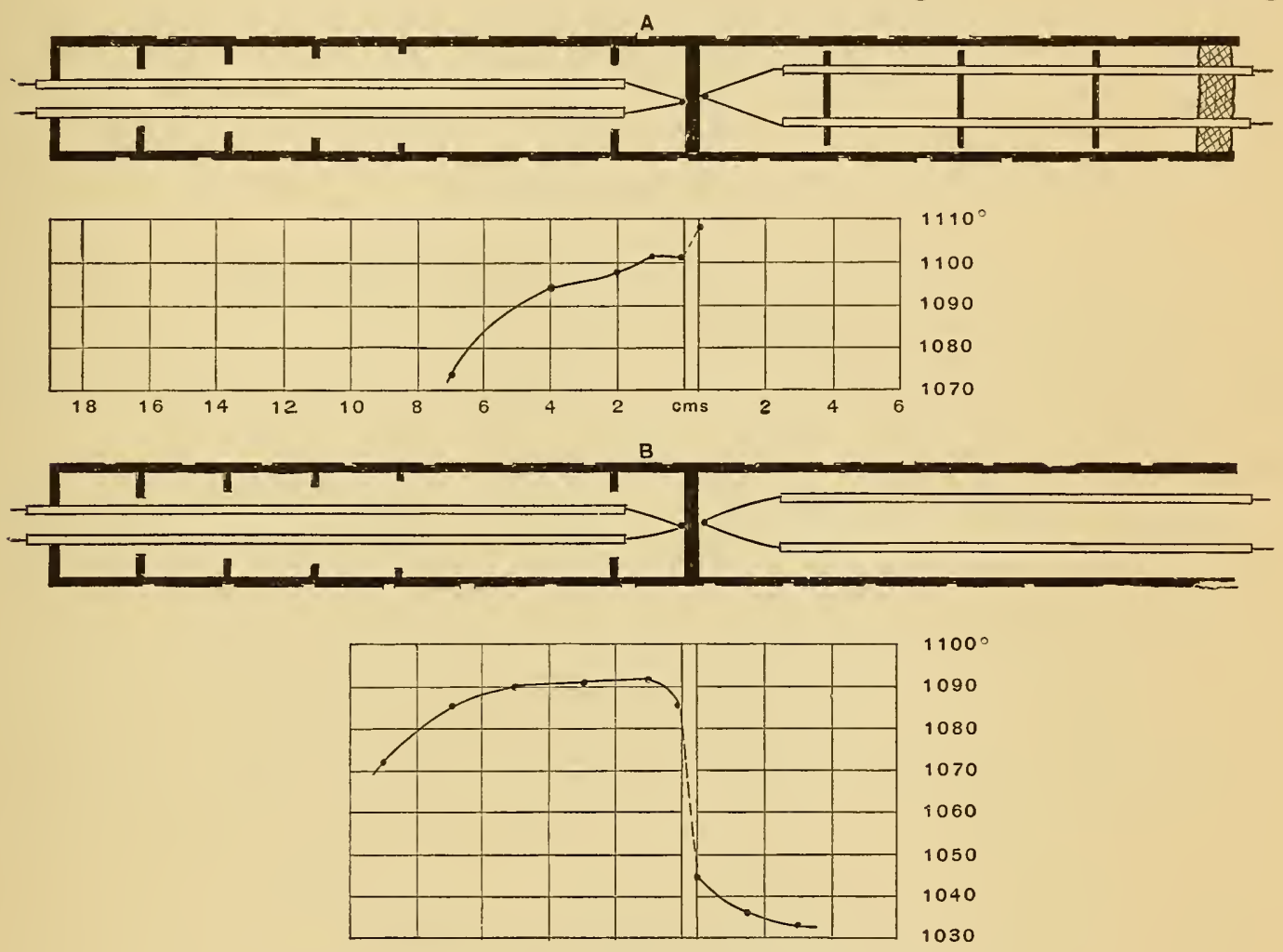

Fig. 1.-Temperature Distribution within Black-Body.

circuit if direct current is used, and to avoid shunt circuits on the couple.

With a view to calling attention to the errors that may arise in the experimental realization of black-body radiation, several cases may be cited. The effect of the temperature gradient in the radiating wall, of the method of measuring the temperature where a thermocouple is used, and of the ratio of size of opening to length of radiator are illustrated in Fig. 2. Here the numbers given below each illustration are the values of the temperature indicated by a 
thermocouple minus the temperature indicated by the optical pyrometer. The arrows indicate the direction in which the optical prrometer was sighted.
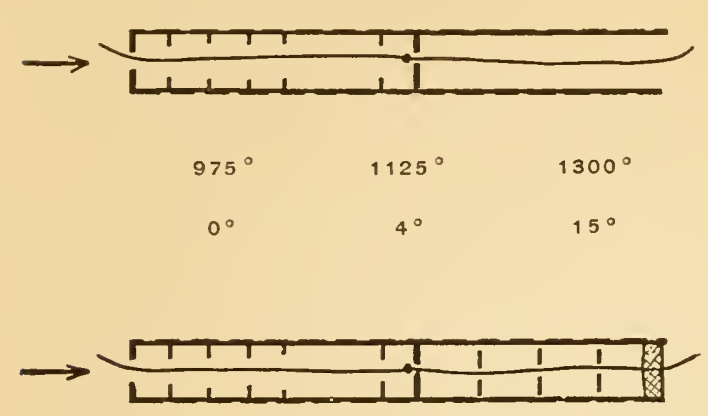

$975^{\circ}$

$1^{\circ}$

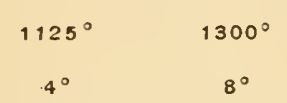

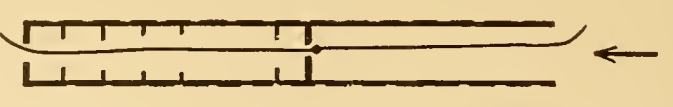

$975^{\circ}$

$1125^{\circ}$

$1300^{\circ}$

$4^{\circ}$

$8^{\circ}$

$10^{\circ}$

Fig. 2.-Approximations to a Black-Body.

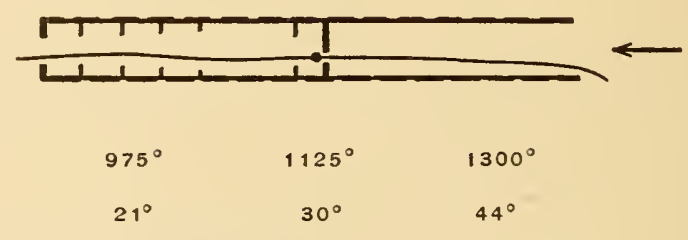

Lamp Calibration.-The pyrometer lamps used in the HolbornKurlbaum pyrometer were four-volt carbon filament lamps, which were aged at a temperature of about $1800^{\circ}$ for a period of twentyfive hours previous to their calibration. These lamps were calibrated by measuring the current when the filament had the same brightness (for red light) as the compensated black-body described above, whose temperature was measured by two thermocouples. The milliammeter with its shunt was calibrated frequently during the progress of the work, and its temperature coefficient determined. The calibration of lamp No. I 40 is cited as an illustration ('Table II).

TABLE II.

Calibration of Lamp 140.

\begin{tabular}{c|c|c|c}
\hline $\begin{array}{c}\text { Temperature } \\
\text { (Observed) }\end{array}$ & $\begin{array}{c}\text { Current } \\
\text { (Observed) }\end{array}$ & $\begin{array}{c}\text { Temperature } \\
\text { (Computed) }\end{array}$ & Temp. obs-Tem. calo \\
\hline $920^{\circ}$ & 0.4486 & $921^{\circ}$ & $-1^{\circ}$ \\
1087.5 & .5305 & 1087.5 & 0 \\
650 & .3357 & 649 & +1 \\
1221 & .6023 & 1221 & 0 \\
692 & .3525 & 692.5 & -0.5 \\
1285 & .6393 & 1285 & 0 \\
1089 & .5309 & 1088.5 & +0.5 \\
\hline
\end{tabular}


The observations are represented by the equation,

$$
I=0.168 \mathrm{I}+0.000 \mathrm{I} 482 t+0.000000 \mathrm{I} 700 t^{2}
$$

where $I=$ current in amperes through the lamp filament, and $t=$ the black-body temperature for red light.

In this table are given the observed currents through the lamp and the corresponding temperatures of the compensated black-body; also the temperature, corresponding to the observed currents, computed from the above equation. In the last column are given the differences between the observed and computed temperatures.

The calibration equations of the five pyrometer lamps are given in Table III.

TABLE III.

Calibration Equations of Pyrometer Lamps.

\begin{tabular}{c|ccc|c|c}
\hline $\begin{array}{c}\text { Lamp } \\
\text { No }\end{array}$ & Equation & & $\begin{array}{c}\text { No. of Cal. } \\
\text { Points }\end{array}$ & $\begin{array}{c}\text { Average dev. } \\
\text { of an obs. }\end{array}$ \\
\cline { 2 - 3 } 132 & $\mathrm{I}=0.1736+0.0_{3} 130 \mathrm{t}$ & $+0.0_{6} 1865 \mathrm{t}^{2}$ & 8 & 1.0 \\
140 & $\mathrm{I}=.1681+.0_{3} 1482 \mathrm{t}$ & $+.0_{6} 1700 \mathrm{t}^{2}$ & 7 & 0.4 \\
145 & $\mathrm{I}=.1600+.0_{3} 1863 \mathrm{t}+.0_{6} 1422 \mathrm{t}^{2}$ & 9 & 1.2 \\
168 & $\mathrm{I}=.1829+.0_{4} 6010 \mathrm{t}+.0_{6} 2348 \mathrm{t}^{2}$ & 9 & 1.7 \\
171 & $\mathrm{I}=.1785+.0_{3} 1179 \mathrm{t}+.0_{6} 2112 \mathrm{t}^{2}$ & 10 & 2.2 \\
\hline
\end{tabular}

The deviation of a single observation from the mean exceeds $3^{\circ}$ at only three points, and the average is $I$. 3 .

The above calibration equations of the lamps, although determined with red glass before the eyepiece of the pyrometer, hold also in practice for any color if a black-body is observed which, it may be remarked, is evidence that a carbon filament is a "gray ${ }^{8}$ body" within the limits of the visible spectrum. This is shown in Table IV.

During the progress of this investigation, the calibration of the lamps was frequently checked by use of the black-body, and no evidence of change in the lamps was detected. For example, near the

${ }^{8} \mathrm{~A}$ body may be said to be gray throughout any spectral region when the ratio of the intensity of its radiation to that of a black-body is the same for all wave lengths within that region. 
conclusion of this investigation a recomparison of the pyrometer lamps with the compensated black-body gave-

Mean Temperature of Black-Body.

By 5 Pyrometer Lamps.

$1018: 0$

1154.5
By Two Thermocouples.

$1017^{\circ} \cdot 6$

1154.9

TABLE IV.

Calibration of Pyrometer Lamps for Red and Green Light.

\begin{tabular}{|c|c|c|c|c|c|}
\hline \multirow{2}{*}{ Lamp No } & \multirow{2}{*}{$\begin{array}{l}\text { Obs. temp. of } \\
\text { the black- } \\
\text { body }\end{array}$} & \multicolumn{2}{|c|}{ Observed current, using: } & \multicolumn{2}{|c|}{ Computed temps., using: } \\
\hline & & Red light & Green light & Red light & Green light \\
\hline 145 & $1261^{\circ}$ & 0.6208 & 0.6188 & $1260: 5$ & $1256: 5$ \\
\hline 168 & 1277 & .6221 & .6229 & 1276 & 1277.5 \\
\hline 171 & 1267.5 & .6675 & .6686 & 1267.5 & 1269 \\
\hline Mean. & $1268: 5$ & & & $1268: 2$ & 1267.8 \\
\hline 140 & 1088.5 & 0.5306 & 0.5303 & $1088: 5$ & $1087^{\circ} .5$ \\
\hline 145 & 1093.0 & .5325 & .5323 & 1091.0 & 1090.5 \\
\hline 168 & 1084.2 & .5242 & .5248 & 1084.7 & 1086.2 \\
\hline Mean. & $1088: 6$ & & & $1088: 1$ & $1088: 1$ \\
\hline
\end{tabular}

Absorption Factors.-In order to determine very high temperatures by extrapolation based on Wien's equation it is usually necessary to diminish the intensity of the radiation in a known ratio by 111eans of absorbing glasses, 111irrors, or sector disks placed in front of the optical pyroneter. The absorption factor $K$ is given by the equation $^{9}$

$$
\log K=c_{2} \frac{\log e}{\lambda}\left(\frac{\mathrm{I}}{T_{1}}-\frac{\mathrm{I}}{T_{2}}\right)
$$

where $\lambda$ is the wave length in $\mu$ of the radiation enployed, $c_{2}$ is take11 as $\mathrm{I} 4,500$ for a black-body, and $T_{1}$ and $T_{2}$ are, respectively,

"If $J_{1}$ and $J_{2}$ are the intensities of the light of wave length $\lambda$, corresponding to the black-body temperatures $T_{1}$ and $T_{2}$ (abs.), then the absorption coefficient is-

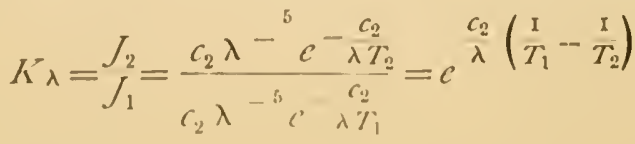


the apparent black-body temperatures (absolute scale) when the radiating source at constant temperature is viewed with and without the absorbing screen.

In the melting point determinations, use was made of the absorbing nirrors of the Holborn-Kurlban111 pyrometer, shown diagran1matically in Fig. 3 .

The intensity of the incident light is diminished by two reflections from black glass. The absorbing glasses furnished by Pellin with the Le Chatelier optical pyrometer were also used.

The absorption factors were determined by sighting the pyrometer on an electrically heated black-body whose temperature was maintained constant to a few tenths of a degree, as indicated by a thermocouple. A single measurement consisted in a series of six to ten observations of $T_{2}$ between two series of observations of $T_{1}$. With the mirror form of absorber, the pyrometer

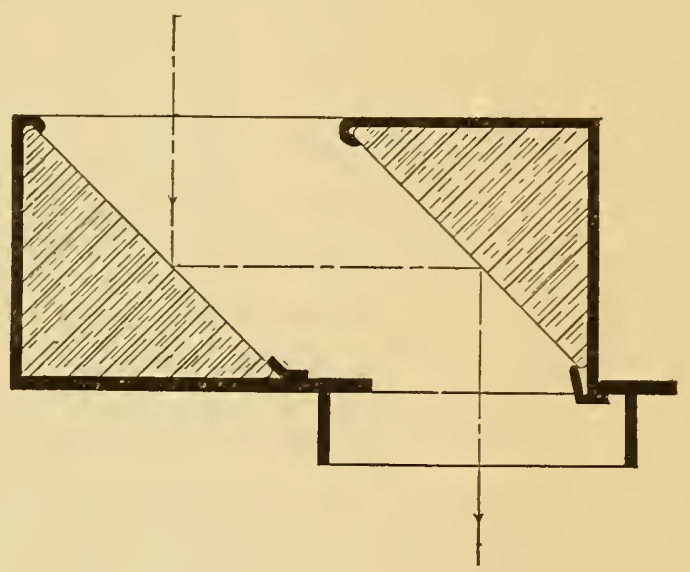

Fig. 3.-Absorption Mirrors. has to be resighted for each set of observations, and as the neighboring parts of the radiating surface may differ somewhat in temperature, there is a small uncertainty introduced into any given value of $K$ from this cause.

The results of the measurements of the absorption factor $K$ of the mirrors, made with red and green light, are given in Table V.

Very small errors in the temperature, measurements will cause considerable errors in the resulting value of $K$; thus an error of $I^{\circ}$ in $T_{2}$ produces 0.8 per cent error in $K$, and $\mathrm{I}^{\circ}$ in $T_{1}$ an error of 2 per cent in $K$. 'Again, two observers may not agree in their estimations of equal brightness at different temperatures; for measurements in the red the two observers differ consistently by 3 per cent in $K$ and in the green by over 5 per cent. The probable errors of $K$ correspond to an uncertainty in the platinum melting point of $\mathrm{I}^{\circ}$ for the red and $2^{\circ}$ for the green. 


\section{TABLE V.}

Absorption Factor of Mirrors.

\begin{tabular}{|c|c|c|c|c|c|c|c|}
\hline \multicolumn{4}{|c|}{$\lambda=0.662 \mu($ Red $)$} & \multicolumn{4}{|c|}{$\lambda=0.547 \mu($ Green $)$} \\
\hline $\begin{array}{l}\text { Lamp } \\
\text { No. }\end{array}$ & $\mathrm{T}_{1}$ & $\mathrm{~T}_{2}$ & $\mathrm{~K}$ & $\begin{array}{c}\text { Lamp } \\
\text { No }\end{array}$ & $\mathbf{T}_{1}$ & $\mathrm{~T}_{2}$ & $\mathrm{~K}$ \\
\hline \multirow{2}{*}{$\begin{array}{c}132 \\
\text { ، }\end{array}$} & $1108: 5$ & $1519^{\circ}$ & 208.4 & \multirow{2}{*}{$\begin{array}{c}171 \\
\text { ، }\end{array}$} & \multirow{2}{*}{$\begin{array}{l}1204: 5 \\
1199.5\end{array}$} & \multirow{2}{*}{$\begin{array}{l}1591: 7 \\
1592\end{array}$} & \multirow{2}{*}{$\begin{array}{l}211.7 \\
232.1\end{array}$} \\
\hline & 1109 & 1513 & 194.9 & & & & \\
\hline \multirow{2}{*}{$\begin{array}{c}171 \\
\text { ، }\end{array}$} & 1150.8 & 1592.6 & 196.1 & \multirow{2}{*}{$\begin{array}{c}168 \\
\text { " }\end{array}$} & 1208 & 1598 & 212.2 \\
\hline & 1152 & 1592 & 191.3 & & 1205 & 1599 & 225.9 \\
\hline \multirow{2}{*}{$\begin{array}{c}168 \\
،\end{array}$} & 1153 & 1595 & 193.1 & \multirow{2}{*}{$\begin{array}{c}140 \\
6\end{array}$} & 1202.5 & 1598 & 233.6 \\
\hline & 1151 & 1595.8 & 201.0 & & 1200 & 1596.5 & 240.8 \\
\hline \multirow{2}{*}{$\begin{array}{c}140 \\
66\end{array}$} & 1151 & 1597.5 & 203.9 & \multirow{2}{*}{$\begin{array}{c}145 \\
6\end{array}$} & 1203 & 1593 & \multirow{2}{*}{$\begin{array}{l}220.4 \\
234.6\end{array}$} \\
\hline & 1149.5 & 1599 & 212.3 & & 1199.5 & 1593 & \\
\hline \multirow{3}{*}{$\begin{array}{c}145 \\
،\end{array}$} & 1152 & 1597 & 199.9 & & & & \\
\hline & 1149 & 1594.5 & 205.7 & \multirow{2}{*}{ - } & & & \\
\hline & & \multicolumn{2}{|c|}{ Mean: $200.6 \pm 1.5$} & & & \multicolumn{2}{|c|}{ Mean: $226.4 \pm 3.0$} \\
\hline
\end{tabular}

Since the mirrors show slight selective absorption and the maxiinnun of visual intensity of the transmission band of the red glasses varies with the temperature (see p. I 75), the value of $K$ must be corrected to correspond to the wave length used. The $\lambda_{\max }$, for the two red glasses usually used at the eye-piece of the pyrometer, has been found to be $0.666 \mu$ and $0.668 \mu$ at black-body temperatures of $\mathrm{I} 55^{\circ}$ and $\mathrm{I} 750^{\circ}$, respectively, for which the corresponding values of $K^{\prime}$ may be taken as 200 and I99. For the monochromatic conlbination 2 Cobalt $+\mathrm{I}$ Jena No. 2745 , whose $\lambda_{\max }$ is $0.720 \mu$ at $\mathrm{I} 55^{\circ}$, $K$ becomes I 86.5 .

If the absorption is strongly selective, as is the case for most transmission glasses, this method of determining $K$ becomes complicated by the fact that the effective wave length is different with and withont the absorption screen, owing to the lack of monochronnatisn1 of the colored glasses used before the eyepiece of the pyrometer, and Wien's equation is no longer directly applicable for the conputation of $K$. 
As a check on this method of measuring $K$, the absorption factor of a sector disk of known opening was determined. The results are given in Table VI.

TABLE VI.

Absorption Factor of Sector Disk.

\begin{tabular}{c|l|l|l}
\hline \multicolumn{3}{|c}{$\operatorname{Red} \lambda_{\max }=0.660 \mu$} \\
\hline Lamp No & \multicolumn{1}{|c|}{$\mathrm{T}_{1}$} & $\mathrm{~T}_{2}$ & $\mathrm{~K}$ \\
\hline 145 & 1225 & 1524.6 & 33.7 \\
168 & 1223 & 1526.5 & 35.6 \\
168 & 1225.5 & 1528 & 34.8 \\
145 & 1220 & 1525.5 & 36.8 \\
& & & Mean: 35.2 \\
\hline
\end{tabular}

The value of $K$ for this disk ${ }^{10}$, from measurements on a circular dividing engine, is 35.45 . The agreement is better than we have any reason to expect, as it corresponds to an accuracy of a few tenths of a degree in the temperature measurements $T_{1}$ and $T_{2}$. The sector disk is free from selective absorption, and the value of $\lambda_{\max }=0.660 \mu$ taken, is that corresponding to $T_{2}=1525^{\circ}$ abs. $\left(\mathrm{I} 25 \mathrm{O}^{\circ} \mathrm{C}\right)$ for the two red glasses used.

A few observations were also made with two absorbing glasses furnished by Pellin with a Le Chatelier optical pyrometer. The absorption factor of the two together was IOI for $\lambda=0.650 \mu$, and about 30 for $\lambda=0.547 \mu$, showing very decided selective absorption.

Effect of Polarization on Absorption Factor.-Owing to the polarization by reflection from polished surfaces, the value of the absorption factor of the mirrors may vary through wide limits if the incident light is polarized, as is the case for light emitted by incandescent platinum ${ }^{11}$ and palladium, the amount of polarization in the emitted radiation being zero for normal incidence and increasing with the angle of incidence.

\footnotetext{
${ }^{10}$ This Bulletin, 2, p. 23; I906.
}

${ }^{11}$ The effect of polarized light emitted by platinum on the indications of the Wanner pyrometer is discussed by the authors in this Bulletin, 1, p. 25I; I905. 
In Table VII are given the results of measurements of the absorption factor of the mirrors when the platinum radiating surface is viewed at an angle of $45^{\circ}$, and when the plane of incidence of the mirrors is, ( $\mathrm{x}$ ) parallel to the plane of emission, and (2) perpendicular to this plane.

TABLE VII.

Polarization and Absorption Factor.

\begin{tabular}{c|c|c|c}
\hline \multicolumn{2}{c|}{$\operatorname{Red}(\lambda=0.660 \mu)$} & \multicolumn{2}{|c}{$\operatorname{Green}(\lambda=0.547 \mu)$} \\
\hline$\|$ & 1 & $\|$ & 1 \\
235 & 165 & 264 & 188 \\
\hline
\end{tabular}

The absorption factors for normal incidence when the polarization is zero, as previously given, is 200 and 226 for red and green, respectively.

Monochromatic Glasses. - If the light used in optical determinations of temperature is not monochromatic, there may be error introduced into the temperature measurements from this cause. Instruments of the spectrophotometer type such as the Wanner pyronneter, using a definite narrow spectral band, are free from this error; but in all instruments employing colored glasses this source of error may become quite serious, varying in general with the temperature, the kind of glass used, and the method of observing. All so-called monochromatic glasses transmit one or more spectral bands of considerable width, variable with the intensity of the incident light. But more important is the fact that the position of maximnun brightness, as estimated by the eye, shifts with the intensity and so with the temperature of the sonrce. When intensities are measured with a bolometer or other instrument whose indications are proportional to the incident energy, the magnitude of the apparent change in temperature for a given change in wave length can be calculated from Wien's equation; but where intensities are estimated by the eye, acconnt must be taken of the variation in sensibility of the eye, which decreases rapidly toward each end of the spectrunn. When the wave length used varies with the temperature, Wien's equation can not be applied directly. 
In view of the above considerations it was deemed important to investigate the optical homogeneity of the glasses used in this work. For this purpose an electrically heated platinum strip, whose temperature was measured by the optical pyrometer, was mounted before the slit of a Fuess spectrometer, by means of which the position of maximum intensity $-\lambda_{\max }$ - and the limits of the transmission bands were studied for different temperatures, and for different thicknesses of glass. The results are given in Table VIII.

TABLE VIII.

Monochromatism of Glasses. ${ }^{12}$

\begin{tabular}{|c|c|c|c|c|}
\hline Glass & $\begin{array}{c}\text { Thickness } \\
\text { of Glass } \\
\text { mm }\end{array}$ & $\begin{array}{l}\text { Tempera- } \\
\text { ture } \\
\text { of Source }\end{array}$ & $\stackrel{\lambda}{\max }$ & $\begin{array}{c}\text { Limits of } \\
\text { Transmission } \\
\text { Band }\end{array}$ \\
\hline \multirow{3}{*}{1 Jena red $\neq 2745 \ldots$} & \multirow{3}{*}{3.04} & $1000^{\circ}$ & $0.645 \mu$ & $0.698 \mu-0.610 \mu$ \\
\hline & & 1250 & .650 & $.731-.602$ \\
\hline & & 1450 & .656 & $.772-.598$ \\
\hline 2 Jena red $¥ 2745 \ldots$. & 6.05 & 1450 & .661 & $.753-.608$ \\
\hline \multirow[t]{2}{*}{2 Pyrometer red glasses.. } & \multirow{2}{*}{5.38} & 1050 & .655 & $.711-.613$ \\
\hline & & 1450 & .664 & $.755-.613$ \\
\hline 2 Jena +1 Pyrometer red... & 8.72 & 1450 & .667 & $.749-.624$ \\
\hline 2 Jena +2 Pyrometer red.... & 11.43 & 1450 & .675 & $.745-.634$ \\
\hline \multirow[t]{2}{*}{1 Cobalt blue (red bands) .. } & \multirow[t]{2}{*}{2.31} & \multirow[t]{2}{*}{1250} & .708 & $.742-.683$ \\
\hline & & & .620 & $.643-.598$ \\
\hline \multirow{2}{*}{2 Cobalt. } & \multirow[b]{2}{*}{4.62} & 1250 & .716 & $.741-.694$ \\
\hline & & 1450 & .716 & $.754-.689$ \\
\hline \multirow[t]{2}{*}{ 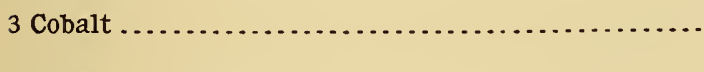 } & \multirow[t]{2}{*}{7.10} & 1450 & .721 & $.755-.701$ \\
\hline & & 1250 & .716 & $.738-.697$ \\
\hline 2 Cobalt +1 Jena red.. & 7.66 & 1450 & .719 & $.750-.693$ \\
\hline \multirow[t]{2}{*}{2 Jena green $¥ 431111 \ldots \ldots \ldots \ldots \ldots \ldots$} & \multirow[t]{2}{*}{6.18} & 1150 & .547 & $.602-.532$ \\
\hline & & 1450 & .546 & $.631-.468$ \\
\hline \multirow{2}{*}{1 Jena blue $\neq 3086$. } & \multirow[b]{2}{*}{4.32} & 1320 & .462 & $.500-.421$ \\
\hline & & 1470 & .462 & $.511-.408$ \\
\hline
\end{tabular}

The limits of the transmission bands here given are defined by the disappearance of the cross-hair of the eyepiece at either edge, although in some cases, notably on the infra red side of the red bands there is a considerable region of vanishing brightness. Independent settings by two observers on $\lambda_{\max }$ agree on the average to better than $0.002 \mu$.

12 The glasses designated "pyrometer red" were furnished with the Holborn. Kurlbaum pyrometer and are probably of the same composition as the Jena red glass No. 2745. The Jena glasses are described by R. Zsigmondy Zs. Instrkunde 21, p. 97; I90r; see also Holborn and Kurlbaum, Ann. der Phys. 10, p. 227; I903. 
An examination of the data shows that as the temperature of the source, i. e., the intensity of the incident light, increases, the width of the transmission band increases for all the glasses. An increase in thickness of a glass cuts down the width of all bands, and in the case of cobalt glass eventually cuts out the second red band. The most important effect, however, for the work in hand, is the shift of the position of maximum brightness in the red glasses toward longer wave lengths with increase in temperature, accompanied by a shift of the maximum in the same direction with increased thickness. For the green and blue glasses the maximum does not shift with temperature within the range studied, but determinations with these glasses, especially with the blue, are relatively less satisfactory.

By the combination of two cobalt blue glasses which give but one red band $\left(\lambda_{\max }=0.716 \mu\right)$ with one Jena red glass No. 2745, which serves to cut ont the green and blue bands transmitted by the cobalt glasses, a glass is obtained which gives a very much narrower band in the red, whose maximum $\left(\lambda_{\max }=0.7\right.$ I $6 \mu-0.7$ I $\left.9 \mu\right)$ shifts less with temperature than any other red monochromatic glass that has come to our attention.

Whether the use of $\lambda_{\max }$, as determined by the eye, for the effective wave length in Wien's equation, is a sufficiently close approximation depends on the variation of intensity and on the sensibility of the eye within the spectral band. This procedure can not lead to errors that are significant for the work in hand. An error of $0.005 \mu$ in wave length involves an error of only about $5^{\circ}$ at the temperature of the melting point of platinum. In the extrapolation to find $\lambda_{\max }$ at $1545^{\circ}$ and $175^{\circ}$, corresponding to the melting points of palladium and platinum, the wave lengths $0.666 \mu$ and $0.668 \mu$ were used, instead of the values given by a linear extrapolation (Table VIII), as the shift of $\lambda_{\max }$ munst become less rapid at high temperatures.

\section{THE RADIATION FROM PLATINUM AND PALLADIUM.}

'The relation of the radiation (red and green) of platinum and palladium to black-body radiation was determined in the temperature range $700^{\circ}-\mathrm{I} 300$ ? The black-body temperature of the incandescent metal was measured with the optical pyrometer. Three methods were used to estinate the actual temperature of the radiating surface. 
In the furnace method, Fig. 4, a platinum ribbon $4 \mathrm{~mm}$ wide was closely wound on a porcelain or quartz tube of about $4 \mathrm{~min}$ external diameter, the space between successive turns being of the order of o. I mm. This small electric furnace was maintained at the desired temperature by a suitable electric current. A thermocouple, threaded through the tube, with its junction at the center of the furnace, was assumed to give the temperature of the platinum ribbon immediately surrounding it. In all, some ten furnaces were used

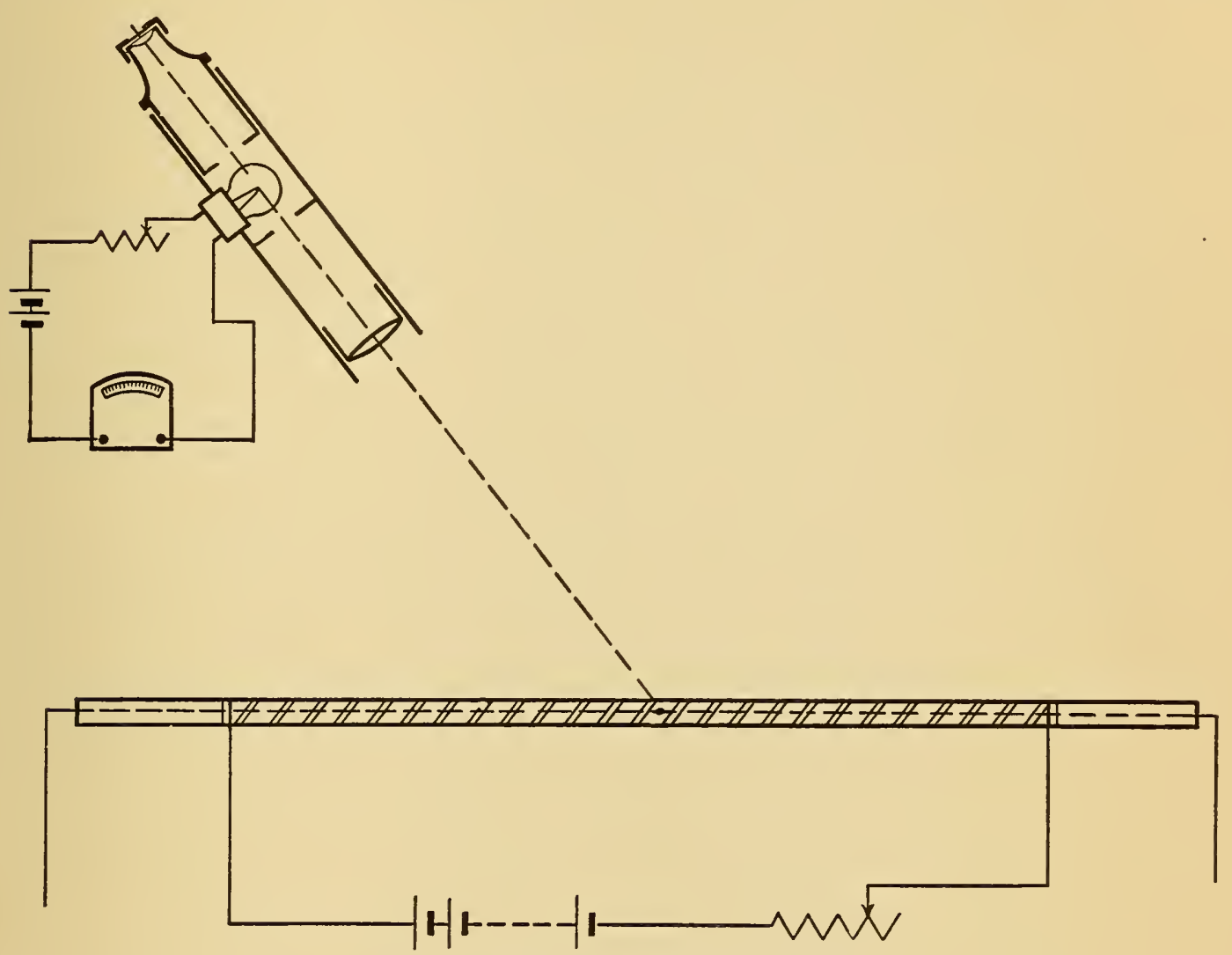

Fig. 4.-Radiation by Furnace Method.

in these experiments. The furnaces were worked practically in the open air to eliminate any possible effect due to light reflected from surrounding walls, blackened asbestos shields affording sufficient protection against sudden temperature fluctuations. The results of the separate determinations are given in Fig. 5 where abscissae are black-body temperatures, $s$, and the ordinates are values of $t-s$, where $t$ is the true temperature. The points on the plot designated by circles were obtained with palladium wound furnaces.

$$
\text { 23835-07-2 }
$$


[Vol. 3, No. 2.

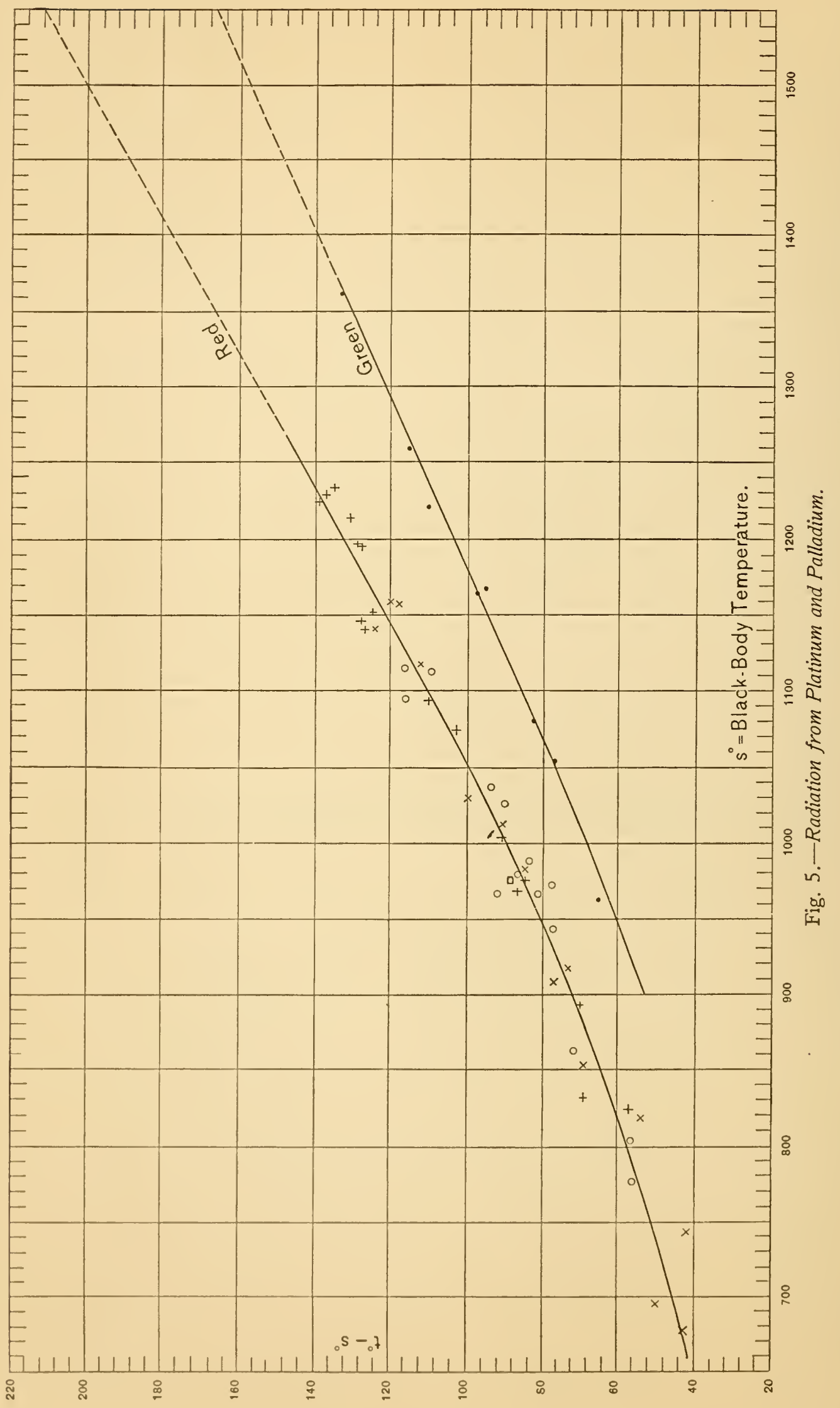


To obtain some idea how nearly the assumption made in this method, viz, that the temperature of the radiating surface is given by the almost completely inclosed thermojunction, the indications of the thermocouple were noted at the instant a minute piece of gold (a few thousandths of a milligram) was observed to melt on the surface of the platinum or palladium ribbon when viewed with a microscope. The following observations on a radiator wound with palladium ribbon will serve as an illustration:

$$
1064^{\circ} \quad \text { I0 }^{\circ} 3^{13} \quad 1063^{\circ} \quad 1066^{\circ}
$$

It will be seen that for this radiator the mean reading of the inclosed thermocouple agrees very well with the melting point of gold $\left(1064^{\circ}\right)$. Unfortunately, the first two radiators examined seemed to substantiate the above assumption so thoroughly that this test was not applied to the remaining radiators. Toward the close of the work, when most of the radiators were no longer available, evidence developed that part of the discrepancies observed may have been due to failure to comply with the above assumption.

In the melting-point method the black-body temperature of an electrically heated platinum or palladium strip was measured with an optical pyrometer at the instant of melting of a minute fragment of gold, as described above. The results of some observations made on the palladium strip by this method are given in Table IX.

This method involves the assumption that the temperature of the platinum (or palladium) ribbon is equal to the melting point of gold at the instant the minute fragment of gold on the ribbon is observed to melt. The agreement of observations made with fragments of very different size indicates that the assumption is quite exactly fulfilled.

The black-body temperature (for $\lambda=0.655 \mu$ ) of platinum (or palladium), as determined from the mean of all the observations by this method, is $975^{\circ}$ at the melting point of gold $\left(1064^{\circ}\right)$, corresponding to

$$
t^{\circ}-s^{\circ}=1064^{\circ}-975^{\circ}=89^{\circ} .
$$

This point is indicated by a square ( $\square$ ) on the curve in Fig. 5 .

${ }^{13}$ Thermojunction was probably displaced from under the portion of the palladium ribbon on which the gold melted. 
By the same method the black-body temperature (for $\lambda=0.666 \mu$ ) of platinum at the melting point of palladium was found to be $1383^{\circ}$. On account of the almost exact equality in the radiation from these two metals this determination was very difficult.

\section{TABLE IX.}

Radiation from Palladium at the Melting Point of Gold.

\begin{tabular}{|c|c|c|}
\hline Lamp No. & $\begin{array}{l}\text { Black-body temperature of palladium } \\
\text { S } \circ \text { for } \lambda=0.655 \mu\end{array}$ & $\mathrm{T}^{\circ}-\mathrm{S}^{\circ}$ \\
\hline 140 & $980^{\circ}$ & $84^{\circ}$ \\
\hline " & 975 & 89 \\
\hline 132 & 976 & 88 \\
\hline$"$ & 974 & 90 \\
\hline 145 & 976 & 88 \\
\hline “ & 976 & 88 \\
\hline 168 & 979 & 85 \\
\hline$"$ & 978 & 86 \\
\hline \multirow[t]{2}{*}{ “ } & 976 & 88 \\
\hline & $977^{\circ}$ & $87^{\circ}$ \\
\hline
\end{tabular}

As a further check on the suitability of the preceding methods for determining the temperature of the radiating surface, a third method, which may be designated as the equal radiation method, was employed. In this method, which is illustrated in Fig. 6, the junction $T_{1}$ of a platinum, platinum-rhodium thermocouple is heated in a colorless Bunsen flame. To protect the flame from convection currents, it is inclosed in a metal cylinder $C$. The current through the radiator, $P t$ is then slowly increased until the brightness of $P t$ is equal to that of the platinum wire of the thermocouple $T_{1}$, which is indicated by the disappearance of the junction when viewed against the radiator $P t$ as background. At this instant, temperature measurements of $T_{1}$ and $T_{2}$ are taken alternately. To insure equal temperature distribution at $T_{1}$, the platinum and the alloy wires were fused together without appreciable enlargement at the junction. In Table $\mathrm{X}$ are given sone observations by this method. 
Waidner.] Melting Points of Palladium and Platinum.
Burgess.

TABLE $\mathrm{X}$.

Temperature of Radiating Platinum Surface.

Temperature given by-

\begin{tabular}{c|c}
\hline Thermocouple $\mathrm{T}_{1}$ in flame & Thermocouple $\mathrm{T}_{2}$ in radiator \\
\cline { 2 - 2 } $1344^{\circ}$ & $1345^{\circ}$ \\
1339 & 1341 \\
1329 & 1327 \\
1332 & 1332 \\
\hline
\end{tabular}

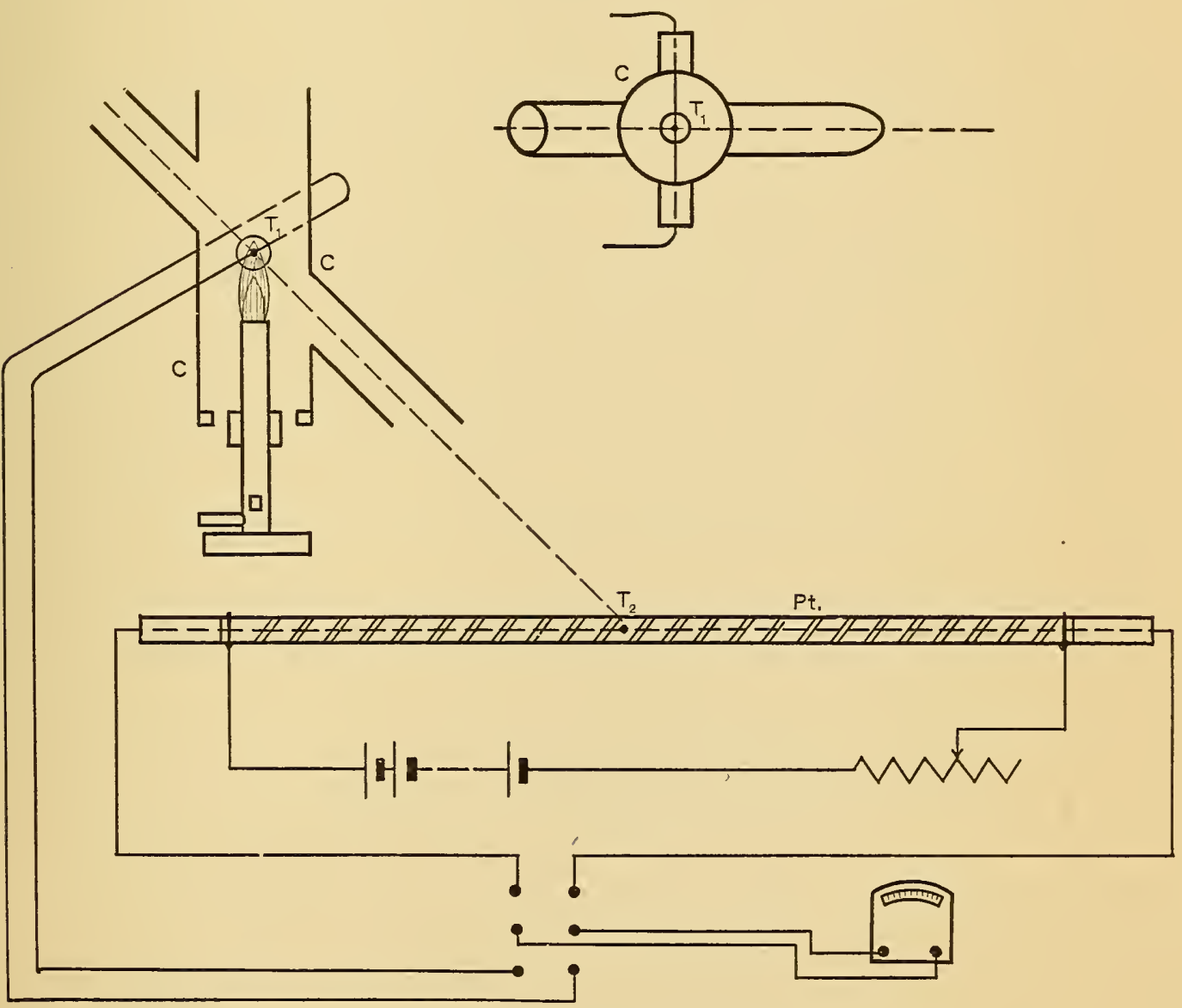

Fig. 6.-Equal Radiation Method.

For this radiator, therefore, the surface temperature of the platinum ribbon was sensibly identical with the temperature indicated by the inclosed thermocouple. 
Some experiments were also made on the radiation from platinum in hydrogen, using the furnace method. For this purpose the platinum radiator was inclosed within a metal inclosure, blackened on the inside, and the radiation observed through a mica window. Alternate series of measurements made in hydrogen and in air at about $900^{\circ}, \mathrm{IIOO}^{\circ}$, and $\mathrm{I} 300^{\circ}$, gave values of $t^{\circ}-s^{\circ}$ about $7^{\circ}$ larger than in air. This difference may be due in part to the absence of oxidation and in part to the greater loss of heat from the surface in hydrogen.

The full curves in Fig. 5 show the relation between $s^{\circ}$ and $t^{\circ}-s^{\circ}$, for the radiation of platinum and palladium in air, for red light, and also for green $(\lambda=0.547 \mu)$. The curve for red light does not apply for strictly monochromatic radiation, as the effective wave length transmitted by the red glasses used before the eyepiece of the pyrometer increases from about $0.65 \mu$ at $800^{\circ}$ to $0.66 \mu$ at I 300 . (See p. I75.)

Some previous observations ${ }^{14}$ based on the assumed melting points of salts and metals, including platinum and palladium, when corrected to the temperature scale to which the present investigation has led, viz, $1546^{\circ}$ for the melting point of palladiun and I $753^{\circ}$ for platinum, are in satisfactory agreement with the results of the later work. The value of $t^{\circ}-s^{\circ}$ for the earlier observations after correction are $9^{\circ}$ higher at $800^{\circ}$, in exact agreement at $\mathrm{r} 100^{\circ}$, and $9^{\circ}$ lower at $r 500^{\circ}$ than the values of $t^{\circ}-s^{\circ}$ given in Fig. 5.

On account of the great difficulty in determining the temperature of a radiating surface, even under the most favorable conditions, as when platinum is used, and the unavoidable changes in character of the surface, a high order of accuracy in the determination of $t^{\circ}-s^{\circ}$ is very difficult of attainment. The effect of constant errors likely to be present in the first two methods employed would be to give low values of $t^{\circ}-s$ ?

\section{MELTING POINTS OF PALLADIUM AND PLATINUM.}

In the work incident to the establishnuent of the lighl tenperature scale during the past three years evidence was obtained, before we had proceeded far, that the scale based on the usual thermoelec- 
tric extrapolation was not in agreement with that defined by the Wien equation, temperatures on the thermoelectric being lower than on the optical scale. Accordingly the determination of the melting points of palladium and platinum was undertaken with the object of finding the magnitude of this difference and, at the same time, establishing suitable fixed points to which the high temperature scale may at any time be referred. In the present communication the results obtained by three different methods are given: (I) Blackbody method using monochromatic radiation; (2) Surface radiation method; (3) Thermoelectric method.

The palladium used in these experiments was obtained from Heræus and from Kahlbaum under specifications calling for the highest attainable purity. Wires of $0.3 \mathrm{~mm}$ and $0.6 \mathrm{~mm}$ were used as well as ribbon $4 \mathrm{~mm}$ wide by $0.02 \mathrm{~mm}$ thick. The platinum was the purest obtainable from Heræus. Samples of the same metal purchased at different times showed no measurable differences in the melting point. The same kind of platinum has been used recently by Nernst and Wartenberg, by Harker, and by Holborn and Valentiner. The temperature coefficient of electrical resistance of this platinum has been found to be higher than that of any other platinum used, which is the most sensitive test of its purity. ${ }^{15}$

\section{BLACK-BODY METHOD.}

The metals were melted in an Heræus tube furnace of pure iridium. The temperature measurements were made with an Holborn-Kurlbaum optical pyrometer, with which absorbing mirrors and a sector disk were used to reduce the intensity of the light by known amounts. The temperatures were computed from the Wien equation (p. I70).

Iridium Furnace.-The iridium tube I (Fig. 7) was $25 \mathrm{~cm}$ long, $2 \mathrm{~cm}$ in diameter, and $0.25 \mathrm{~mm}$ wall thickness. To avoid destructive evaporation of the iridium and contamination of the platinum and palladium, the iridium tube was coated inside and out with the

\footnotetext{
15 The purity of these metals is discussed by Mylius and Dietz, Berichte Deutsch. Chem. Ges. 31, p. 3 I87, I899.
} 
refractory earth mixture ${ }^{16}$ due to Nernst. The interior of the furnace was recoated several times during the progress of the work.

The iridium tube was platinum-soldered at each end to a platinum disk which was bolted to silver alloy terminal springs $A$. This construction allows the iridium tube to expand freely and so prevents buckling of the iridium tube.

The furnace was heated by means of an alternating current supplied by two 3 -kw transformers with primaries $P_{1}$ and $P_{2}$ in parallel and secondaries $S_{1}$ and $S_{2}$ in series. The transformers were operated from an alternator connected directly with a motor which was run from a
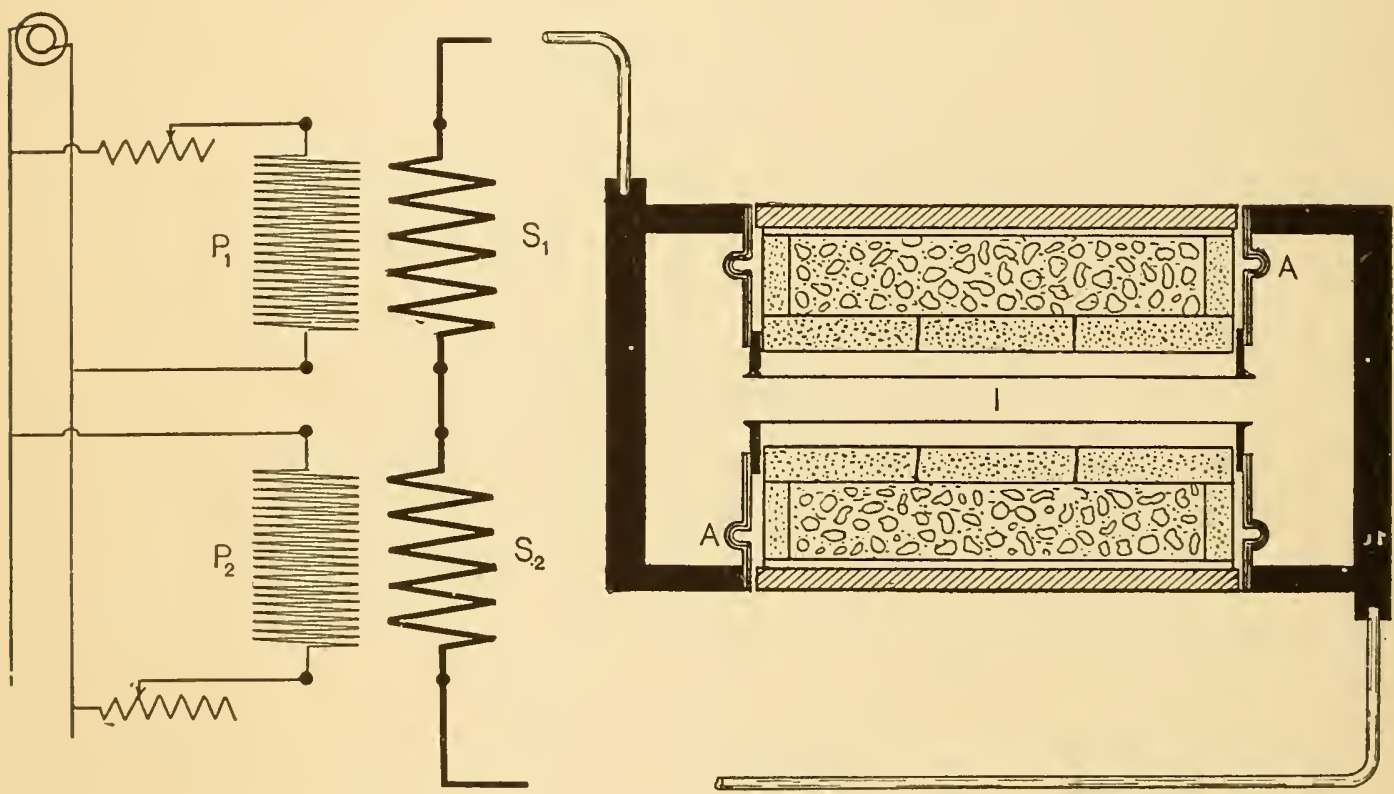

Fig. 7.-Iridium Tube Furnace.

storage battery, so that very exact temperature regulation was possible by the use of suitable rheostats in the primary circuits. The furnace was used in a horizontal position. To prevent convective circulation and to give a more uniform temperature distribution, one end was closed with an asbestos plug.

Approximation to Black-Body Radiation.-As the pyrometer lamps were calibrated by the use of a nearly ideal black-body (p. 165), it was possible to test low closely the iridium furnace as

${ }^{16}$ IO grams zircon-oxychloride and 2 grams yittrium-nitrate are dissolved in 60 cc of water, and pure finely ground thorium oxide is added to form a thin paste which is applied with a brush. 'The furnace should be heated to $1600^{\circ}$ and recoated several times. 
used satisfied this condition. This was done for several temperatures. The black-body temperature of melting gold was found to be $1063^{\circ}$ from six determinations all lying between $1062^{\circ}$ and I06 $4^{\circ}$, which agrees very closely with the true temperature, Io64. Again, the black-body temperature of a coated iridium disk near the center of the furnace, as measured with these lamps, was $1306^{\circ}$, and the true temperature, as given by the thermocouples, was I $307^{\circ}$. Other corroborative measurements were made at intermediate temperatures.

From the final differences found between the extrapolated thermoelectric scale and the Wien scale (p. 205), it follows that the differences between these two scales at $1300^{\circ} \mathrm{C}$ is about $2^{\circ}$ or $3^{\circ}$. These experiments therefore indicate that the departure of the radiation of the iridium furnace from the practically ideal black-body radiation in terms of which the pyrometer lamps are calibrated, is $\mathrm{I}^{\circ}$ at I064 $4^{\circ}$ and about $3: 5$ at I 300 . The corrections for "lack of perfect blackness" at the melting points of palladium and platinum are therefore about $6^{\circ}$ and $8^{\circ}$, respectively. As the surrounding walls of the furnace are at a slightly higher temperature than the radiating body under observation, the lack of blackness is in part offset by reflection from that body.

Methods of observation.- To determine the possible effect of contamination of the metals by iridium, some melts were taken with the metal (platinum) completely inclosed in tubes of fused magnesia; ${ }^{17}$ others were taken with the pyrometer sighted on the bare platinum hammered into a disk; and a few melts were also taken by sighting upon the coated iridium disk, immediately behind which the platinum was placed. The instant of melting for the first and last methods was determined by the interruption of an electric circuit, while for the second the melting could be seen. The above methods gave no measurable difference. The rate of rise of temperature at the melting point was varied within the limits $2^{\circ}$ to $I 5^{\circ}$ per minute, the usual rise being about $5^{\circ}$

Reduction of an observation.-The following example will serve to illustrate the method of determining the temperature at the instant of melting. When the temperature had approached to within

\footnotetext{
${ }^{17}$ The authors are greatly indebted to Mr. J. A. Heany of York, Pa., for tubes of fused pure magnesia.
} 
I $5^{\circ}$ or $20^{\circ}$ of the melting point, observations were begun and continued up to or, where possible, a few degrees beyond the melting point. The time-temperature plot was then drawn (Fig. 8) and the temperature corresponding to the instant of melting was found by interpolation. This procedure gives a considerably higher accuracy than a single observation.

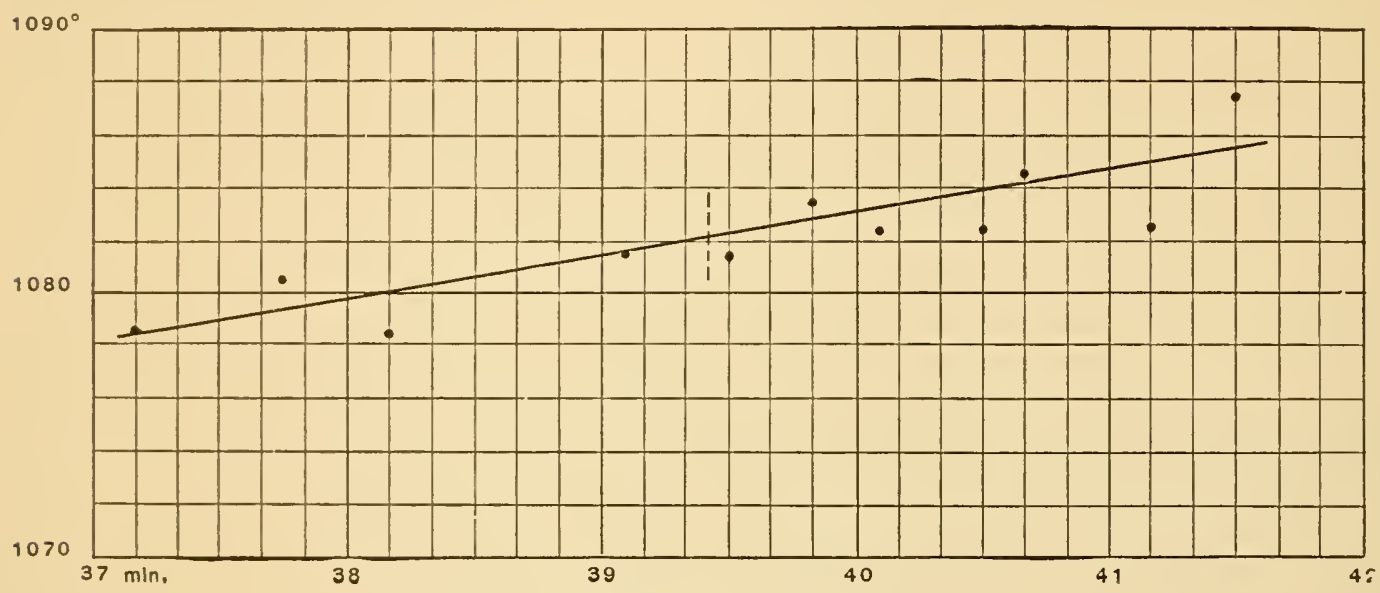

Fig. 8.-Melting Point by Interpolation.

The plot gives $1082^{\circ}\left(T_{1}=\mathrm{I} 355^{\circ}\right.$ abs. $)$ for the black-body temperature of the melting metal (platinum) as observed through the absorbing mirrors whose coefficient of absorption, $K$, equals 200. Substituting the above values of $T_{1}$ and $K$ in the Wien equation,

$$
\log K=c_{2} \frac{\log e}{\lambda}\left(\frac{\mathrm{I}}{T_{1}}-\frac{\mathrm{I}}{T_{2}}\right),
$$

where $c_{2}=\mathrm{I} 4500$ and $\lambda=0.668 \mu$, we have $T_{2}=2023^{\circ} \mathrm{abs} .=\mathrm{I} 750^{\circ} \mathrm{C}$.

Palladium.-Four series of observations were taken on the melting point of palladium, two with the absorbing mirrors, one with the ten degree sector disk, and one without any absorption screen, Table XI. The second series with the absorbing mirrors was taken several montlis after the first. The series without any absorbing screens gives a determination of the melting point by a method which is not based on Wien's equation but on direct extrapolation by the calibration equations (p. I69) of the pyrometer lamps. The series with the sector disk was taken after the work on platinum when the furnace had developed local irregularities in its temperature distribution. 
TABLE XI.

Melting Point of Palladium in Iridium Furnace.

BY WIEN'S EQUATION.

With Absorbing Mirrors $\mathrm{K}=200, c_{2}=14500, \lambda=0.666 \mu$.

\begin{tabular}{|c|c|c|c|}
\hline Lamp No & Current in Lamp & $\begin{array}{l}\text { Observed M.P. Black- } \\
\text { body Temperature }\end{array}$ & Melting Point \\
\hline 132 & 0.4827 & $984^{\circ}$ & $1538^{\circ}$ \\
\hline “ & .4838 & 986 & 1542 \\
\hline 145 & .4808 & 983.5 & 1537 \\
\hline “ & .4823 & 987 & 1544 \\
\hline 171 & .4991 & 984 & 1538 \\
\hline “ & .4989 & 983.5 & 1537 \\
\hline 168 & .4704 & 986 & 1542 \\
\hline \multirow[t]{2}{*}{ “ } & \multirow[t]{2}{*}{.4711} & \multirow[t]{2}{*}{987} & 1544 \\
\hline & & & $1540^{\circ}$ \\
\hline 132 & .4822 & 983 & 1536 \\
\hline$"$ & .4827 & 984 & 1538 \\
\hline " & .4842 & 987 & 1544 \\
\hline 168 & .4709 & 986.5 & 1543 \\
\hline “ & .4692 & 983.5 & 1537 \\
\hline 171 & .4982 & 983 & 1536 \\
\hline \multirow[t]{2}{*}{ “ } & \multirow[t]{2}{*}{.4997} & \multirow[t]{2}{*}{985} & 1540 \\
\hline & & & $1539^{\circ}$ \\
\hline
\end{tabular}

With Sector Disk $K=35.4, c_{2},=14500, \lambda=0.666 \mu$.

171, 132, 145, 168, 11 Observations, $\quad \mathbf{1 1 2 4}: 5$.

1540 ?

BY LAMP CALIBRATION.

\begin{tabular}{c|c|c}
\hline Lamp No & Current in Lamps & Melting Point \\
\hline 132 & 0.8220 & $1547^{\circ}$ \\
“ & .8219 & 1547 \\
145 & .7895 & 1548 \\
“ & .7900 & 1549 \\
171 & .8654 & 1546 \\
“ & .8665 & 1547 \\
& & $1547^{\circ}$ \\
\hline
\end{tabular}


TABLE XII.

Melting Point of Platinum in Iridium Furnace.

BY WIEN'S EQUATION.

With Absorbing Mirrors $\mathrm{K}=199, \mathrm{c}_{2}=14500, \lambda=0.668 \mu$ (Red).

\begin{tabular}{|c|c|c|c|}
\hline Lamp No & $\begin{array}{l}\text { Current in Lamp } \\
\text { Amperes }\end{array}$ & $\begin{array}{l}\text { Observed M. P. Black- } \\
\text { body Temperature }\end{array}$ & Melting Point \\
\hline 145 & 0.5280 & $1081: 5$ & $1749^{\circ} \mathrm{C}$ \\
\hline 168 & .5227 & 1082 & 1750 \\
\hline " & .5227 & 1082 & 1750 \\
\hline 171 & .5526 & 1081 & 1748 \\
\hline " & .5516 & 1079 & 1744 \\
\hline " & .5531 & 1081 & 1750 \\
\hline " & .5526 & 1081 & 1748 \\
\hline " & .5526 & 1081 & 1748 \\
\hline “ & .5516 & 1079 & 1744 \\
\hline 145 & .5271 & 1080 & 1746 \\
\hline$"$ & .5281 & 1082 & 1750 \\
\hline 132 & .5321 & 1079.5 & 1745 \\
\hline " & .5306 & 1076.5 & 1738 \\
\hline " & .5311 & 1077.5 & 1741 \\
\hline " & .5321 & 1080 & 1746 \\
\hline \multirow[t]{2}{*}{145} & \multirow[t]{2}{*}{.5245} & \multirow[t]{2}{*}{1074.5} & 1735 \\
\hline & & & $1746^{\circ}$ \\
\hline 145 & .5247 & $1075^{\circ}$ & $1736^{\circ} \mathrm{C}$ \\
\hline$"$ & .5271 & 1080 & 1746 \\
\hline " & .5257 & 1077 & 1740 \\
\hline 132 & .5338 & 1082.5 & 1751 \\
\hline “ & .5323 & 1080 & 1746 \\
\hline “ & .5334 & 1082 & 1750 \\
\hline \multirow[t]{2}{*}{ “ } & \multirow[t]{2}{*}{.5311} & \multirow[t]{2}{*}{1077.5} & 1741 \\
\hline & & & $1744^{\circ}$ \\
\hline
\end{tabular}

With Absorbing Mirrors $\mathrm{K}=228, \mathrm{c}_{2}=14500, \lambda=0.547 \mu$ (Green).

\begin{tabular}{c|c|c|c}
\hline 145 & 0.5653 & $1156^{\circ}$ & $1747^{\circ} \mathrm{C}$ \\
132 & .5748 & 1158 & 1750 \\
"6 & .5746 & 1157.5 & 1749 \\
168 & .5646 & 1153.5 & 1742 \\
171 & .5948 & 1152.5 & 1740 \\
"6 & .5945 & 1152 & 1739 \\
145 & .5641 & 1153.5 & 1742 \\
\hline
\end{tabular}


TABLE XIII.

Melting Point of Platinum in Iridium Furnace.

BY WIEN'S EQUATION.

With Sector Disk $K=35.4, c_{2}=14500, \lambda=0.668 \mu$ (Red).

\begin{tabular}{|c|c|c|c|}
\hline Lamp No & $\begin{array}{l}\text { Current in Lamp } \\
\text { Amperes }\end{array}$ & $\begin{array}{l}\text { Observed M. P. Black- } \\
\text { body Temperature }\end{array}$ & Melting Point \\
\hline 168 & 0.6189 & $1241^{\circ}$ & $1743^{\circ} \mathrm{C}$ \\
\hline " & .6189 & 1241 & 1743 \\
\hline 132 & .6224 & 1240 & 1741 \\
\hline “ & .6241 & 1242.5 & 1745 \\
\hline 6 & .6246 & 1243.5 & 1747 \\
\hline 145 & .6105 & 1242 & 1744 \\
\hline “ & .6101 & 1241 & 1743 \\
\hline 171 & .6508 & 1242 & 1744 \\
\hline “ & .6525 & 1245 & 1750 \\
\hline \multirow[t]{2}{*}{ “ } & \multirow[t]{2}{*}{.6518} & \multirow[t]{2}{*}{1243.5} & 1747 \\
\hline & & & $1745^{\circ}$ \\
\hline
\end{tabular}

With Sector Disk K $=35.4, c_{2}=14500, \lambda=0.547 \mu$ (Green).

\begin{tabular}{|c|c|c|c|}
\hline 171 & 0.6983 & $1314: 5$ & $1745^{\circ} \mathrm{C}$ \\
\hline "6 & .6948 & 1309 & 1739 \\
\hline 145 & .6463 & 1306.5 & 1736 \\
\hline " & .6478 & 1309.5 & 1740 \\
\hline 132 & .6643 & 1309 & 1739 \\
\hline \multirow[t]{2}{*}{$"$} & \multirow[t]{2}{*}{.6658} & \multirow[t]{2}{*}{1311.5} & 1741 \\
\hline & & & $1740^{\circ}$ \\
\hline
\end{tabular}

With Sector Disk $K=35.4, c_{2}=14500, \lambda=0.462 \mu$ (Blue).

\begin{tabular}{c|c|c|c}
\hline 132 & 0.6968 & $1361^{\circ}$ & $1736^{\circ} \mathrm{C}$ \\
" & .7018 & 1369 & 1746 \\
168 & .7020 & 1364 & 1740 \\
" & .7028 & 1366 & 1742 \\
& & & $1741^{\circ}$ \\
\hline
\end{tabular}


Platinum.-Three series of observations of the platinum melting point were taken with the absorbing mirrors, Table XII, two with red and one with green light. Three series were taken with the sector disk, Table XIII, using respectively red, green, and blue light. In the first series with red light, using the mirrors, Table XII, the platinum was completely inclosed in small tubes of fused magnesia; in the second, the platinum was hammered out into a small disk and observed directly; in the third series, with green light, the platinum was protected with magnesia. The results in the table show that there was no appreciable contamination of the exposed platinum. Most of the observations with the sector disk, Table XIIr, were taken with uncovered platinum. The results of the measurements of both platinum and palladium are discussed subsequently (pp. 202 et seq.).

\section{SURFACE RADIATION METHOD.}

In this method the black-body temperature of exposed strips of platinum or palladium at its melting point was observed by means of the optical pyronleter. The relation between the true temperature and the corresponding black-body temperature is assumed to be that given by extrapolation of the relation investigated experimentally to $1250^{\circ} \mathrm{C}$. (p. I78). This method is not susceptible of the accuracy of the preceding one, and we regard the results only as corroborative evidence that the usual extrapolated thermoelectric relation gives too low temperatures.

Although the black-body temperature of a radiating surface may be measured with very considerable accuracy, it is difficult to pass from this to the true temperature, as it is necessary to know for the material nnder observation the relation of its radiation to black-body radiation. 'This is difficult to determine within the range of known temperatures (abont $\mathrm{I} 200^{\circ}$ ), and is therefore attended with greater nncertainty when extrapolation nunst be resorted to. The surface changes due to very high temperatures, such as pitting, oxidation, and crystallization, might be expected to increase the "blackness" of the radiation (i. e., $t-s$ wonld increase less rapidly, due to this canse), and consequently this method would give a maximum value for the true temperature of the melting point. 
It is evidently possible to determine experimentally the relation between $t^{\circ}$ and $s^{\circ}$ above $1250^{\circ}$ by the use of the extrapolated thermoelectric scale, but this would then not be a method independent of the thermoelectric scale. In this way Holborn and Henning ${ }^{18}$ were led to $1729^{\circ}$ and $\mathrm{I} 549^{\circ}$ for the melting points of platinum and palladium, respectively.

In the present experiments the pyrometer was sighted on the hottest portion of a metallic strip, $4 \mathrm{~mm}$ wide, $0.02 \mathrm{~mm}$ thick, and about $8 \mathrm{~cm}$ long. The strip was slowly raised to the melting point by means of an electric current, and the reading of the pyrometer taken at the instant of melting.

Palladium.-In Table XIV are given the results of the experiments on the melting point of palladium in terms of the black-body temperatures for red, green, and blue light by extrapolation of the lamp calibration equations; and also for red light by extrapolation of the Wein equation, using the absorbing mirrors.

By linear extrapolation of the curve giving the relation between the black-body temperature and the true temperature (p. I78) the value of $t^{\circ}-s^{\circ}=\mathrm{I} 74$ for $s=\mathrm{I} 387^{\circ}$, so that this method gives for the corresponding temperature of the melting point of palladium $156 \mathrm{I}^{\circ}$ for the observations with red light. Similarly the observations with green light give $t=\mathrm{I} 425+\mathrm{I} 44=\mathrm{I} 569^{\circ}$. Experimental evidence indicates that the surface of palladium deteriorates more than that of platinum at high temperatures, so that the linear extrapolation gives too high values for $t-s$ for palladium.

Platinum.- In the experiments on platinum, Table XV, the same procedure was followed as for palladium. In the experiments based on Wien's equation the absorbing mirrors were used in two positions, with the line of sight normal to the radiating surface and at an angle of about $45^{\circ}$. As has already been shown (p. I74), the coefficient of absorption of the mirrors is different in these two cases owing to the polarization of the light. Two absorbing glasses from Pellin (p. I73) were also used by this method. The use of the lamp calibration equations gives a slightly higher result than the Wien equation, as was also found by the furnace method (p. I87).

${ }^{18}$ Holborn and Henning, Berichte d. Berlin Akad., 12, p. 3II; I905. 


\section{TABLE XIV.}

Melting Point of Palladium with Palladium Ribbon.

BY WEIN'S EQUATION.

With Absorbing Mirrors $K=203, c_{2}=14500, \lambda=0.652 \mu$ (Red).

\begin{tabular}{c|c|c|c|c}
\hline Lamp No. & $\begin{array}{c}\text { Number of } \\
\text { Observations }\end{array}$ & $\begin{array}{c}\text { Mean Current in } \\
\text { Lamps }\end{array}$ & $\begin{array}{c}\text { Observed Black-body } \\
\text { Temperature }\end{array}$ & $\begin{array}{c}\text { Melting Point, Black- } \\
\text { body Temperature }\end{array}$ \\
\cline { 1 - 2 } 140 & 6 & 0.4473 & $918^{\circ} \mathrm{C}$. & $1391^{\circ} \mathrm{C}$. \\
168 & 6 & .4353 & 916.5 & 1389 \\
145 & 6 & .4501 & 916 & 1388 \\
& & & & $1389^{\circ}$
\end{tabular}

BY LAMP CALIBRATION.

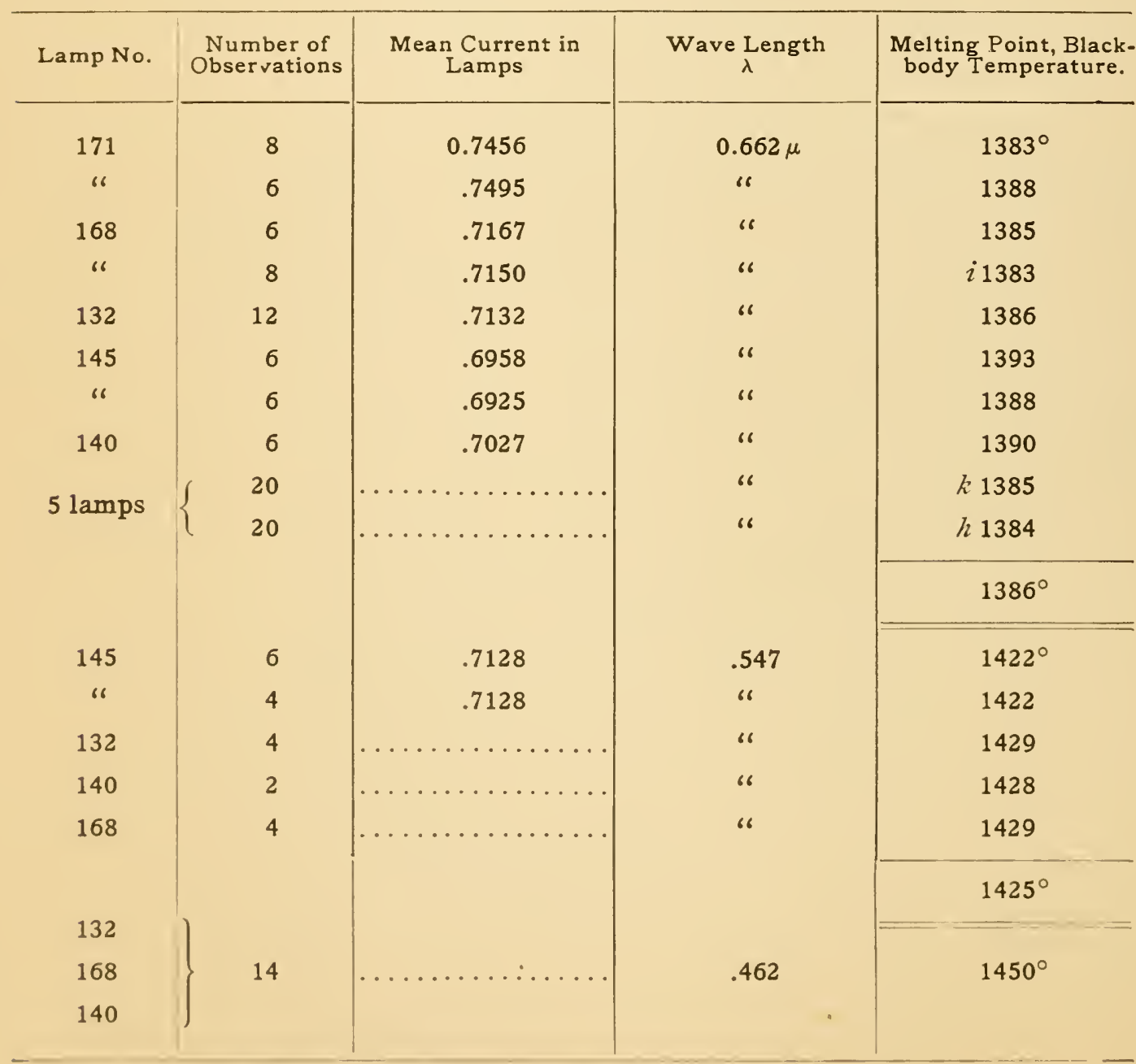

$i$ Palladium melted on Platinum strip. $k=$ Kahlbaum Pd; $h=$ Heræus Pd. 
Waidner.] Melting Points of Palladium and Platinum.
Burgs.

TABLE XV.

Melting Point of Platinum with Platinum Ribbon.

BY WEIN'S EQUATION.

\begin{tabular}{|c|c|c|c|c|c|c|}
\hline $\begin{array}{l}\text { Lamp. } \\
\text { No. }\end{array}$ & $\begin{array}{c}\text { Wave } \\
\text { Length } \\
\text { Length }\end{array}$ & Absorbing Screen & $\underset{K}{\text { Abs, coef. }}$ & $\begin{array}{c}\text { Number } \\
\text { of } \\
\text { Obser- } \\
\text { vations. }\end{array}$ & $\begin{array}{c}\text { Observed } \\
\text { Black-body } \\
\text { Temperature. }\end{array}$ & $\begin{array}{c}\text { Melting } \\
\text { Point, } \\
\text { Black-body } \\
\text { Tempera- } \\
\text { ture. }\end{array}$ \\
\hline 132 & $0.666 \mu$ & Mirrors $\perp$ & 200 & 9 & $983: 5 \mathrm{C}$ & $1537^{\circ} \mathrm{C}$ \\
\hline 140 & " & "6 & 6 & 6 & 979 & 1527 \\
\hline 145 & 66 & “6 & "6 & 6 & 982 & 1534 \\
\hline " & "6 & Mirrors $45^{\circ}$ & 164 & 10 & 996 & 1533 \\
\hline 140 & 6 & "6 & 66 & 8 & 996 & 1533 \\
\hline " & .650 & 2 Pellin glasses & 101 & 8 & 1044 & 1537 \\
\hline \multirow[t]{2}{*}{145} & 66 & " & " & 6 & 1044.5 & 1538 \\
\hline & \multirow{5}{*}{$\begin{array}{c}.547 \\
6 \\
6\end{array}$} & & & & & $1534^{\circ}$ \\
\hline 145 & & Mirrors 1 & 226 & 8 & 1070 & 1579 \\
\hline 140 & & 6 & 66 & 8 & 1071 & 1581 \\
\hline \multirow[t]{2}{*}{145} & & Mirrors $45^{\circ}$ & 188 & 4 & 1077 & 1568 \\
\hline & & & & & & $1578^{\circ}$ \\
\hline
\end{tabular}

BY LAMP CALIBRATION.

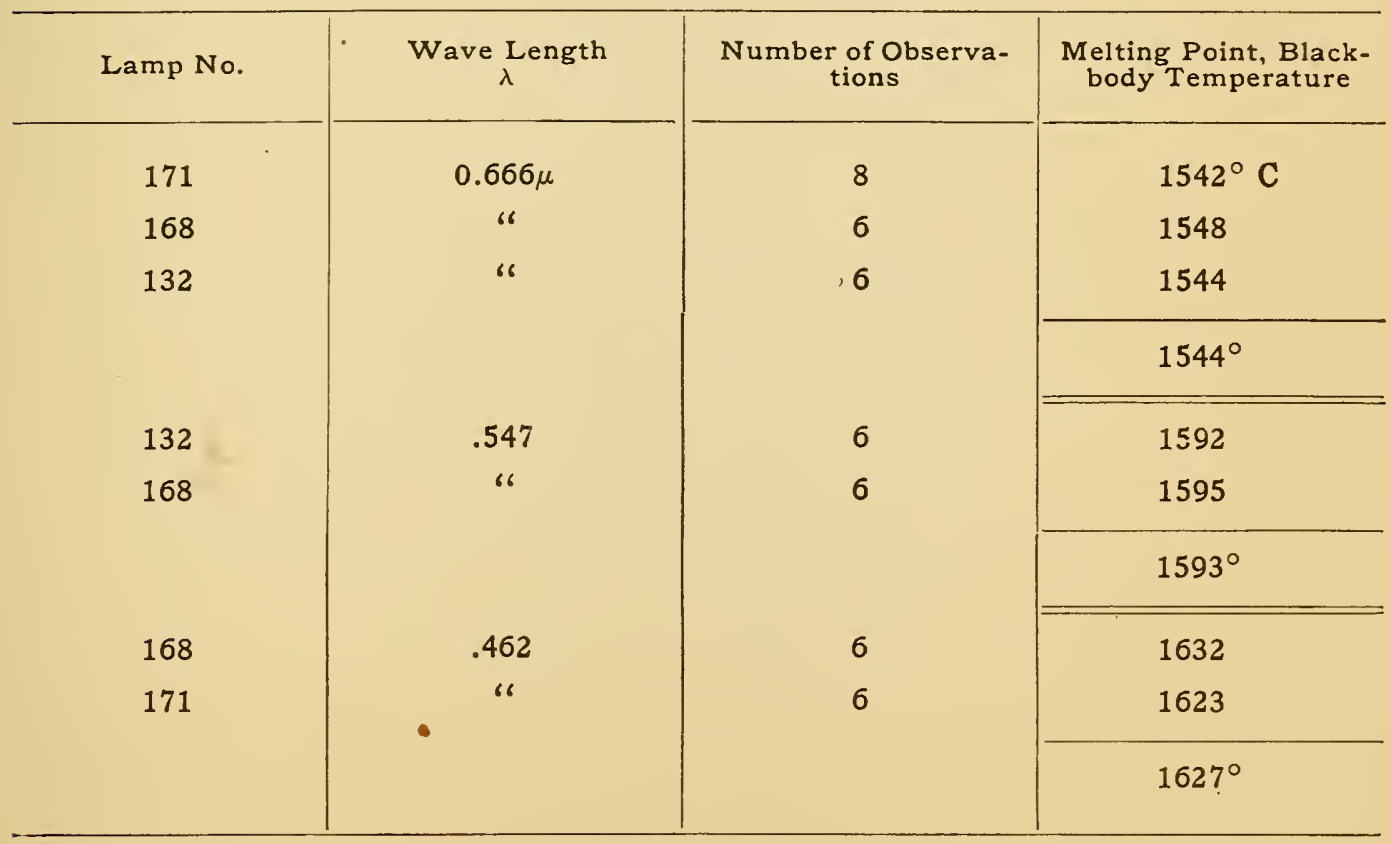

$23835 \multimap 07-3$ 
By the same method used for palladium, we find for the temperature of the melting point of platinum, from the experiments with red and green, respectively:

$$
\begin{aligned}
& t=\mathrm{I} 539+209=\mathrm{I} 74^{\circ} \text { (red). } \\
& t=\mathrm{I} 5^{8} 5+\mathrm{I} 72=\mathrm{I} 757^{\circ} \text { (green). }
\end{aligned}
$$

The experiments with red are entitled to a much greater weight than those with green light.

\section{THERMOELECTRIC METHOD.}

Palladium.-The wire method, frequently used in the calibration of thermocouples at the melting points of silver and gold, was used in these determinations. A short length ( 3 to $6 \mathrm{~mm}$ ) of palladium wire was fused between the platinum and the platinum-rhodium or platinum-iridium wires of the thermocouple. The couple was mounted with this junction near the center of an electric furnace. The heating current through the furnace was then increased, slowly raising the temperature, while readings of the E. M. F. of the conple were taken rapidly on the potentiometer until the palladium connecting link melted. Suitable commutator switches, designed to reduce stray thermal E. M. F.s to a minimum, permitted the reversal of the potentiometer current and the connections of the couple during the heating.

The furnaces used in this work were modified Heræus resistance furnaces, with porcelain tubes, about $20 \mathrm{~mm}$ internal diameter, wound over a length of about 25 cms with platinum ribbon about 2011111 wide and $0.007 \mathrm{~mm}$ thick.

Various metlods of mounting the couple were tried. In some of the earlier experiments the couple was stretched through the furnace in a horizontal position, withont, however, being in contact with its walls; in others, the wires of the couples were run through Berlin porcelain tubes ( 2 mm internal, $4 \mathrm{~mm}$ external dianeter). On acconnt of the n11avoidable sliglit differences in temperature between the two ends of the short palladiun wire, a vertical arrangenent of the furnace, ${ }^{19}$ shown in Fig. 9, was used in the later experiments. This mominting also elininiated the possible effect of tension on the wire.

\footnotetext{
${ }^{19}$ Although shown in a horizontal position in the illustration, the furnace was used in a vertical position.
} 
At these high temperatures porcelain begins to soften and also becomes conducting, so that care must be taken to eliminate the effect of any leakage of the heating current to the thermocouple circuit. Some preliminary experiments, made in a small porcelain tube furnace $5 \mathrm{~mm}$ internal diameter with the wires of the couple resting on the procelain, gave quite discordant results due to this cause. When the couple was mounted, as indicated in Fig. 9, a reversal of the furnace heating current showed entire absence of leakage. In some of the earlier experiments with other forms of mounting there was a slight leakage, which, however, was always determined by taking observations of the E. M. F. of the couple, a few degrees below the melting point, with the heating current alternately reversed. The correction for leakage never exceeded $3^{\circ}$,

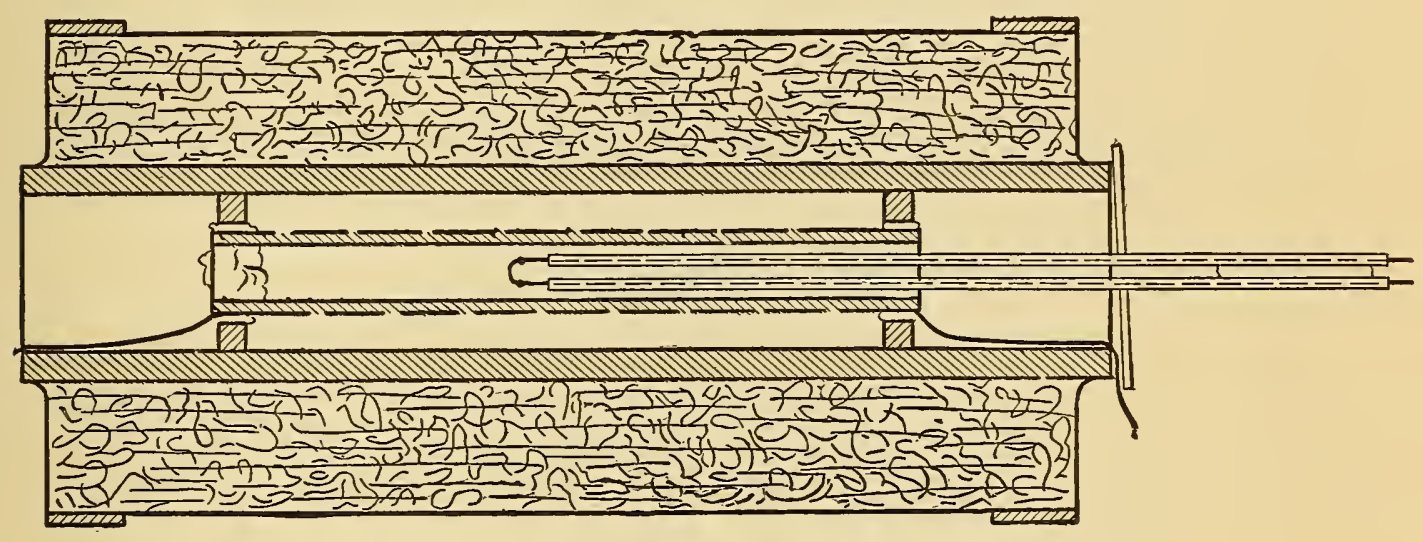

Fig. 9.-Furnace for Palladium Melting Point.

and the results obtained, when this correction is applied, agree with the later determinations.

The palladium used was in the form of wire and twisted strips, furnished as chemically pure by Heræus and by Kahlbaum. Wires of two sizes ( $0.6 \mathrm{~mm}$ and $0.3 \mathrm{~mm}$ ) were used, which, together with the strips, allowed any possible effect of strain in interrupting the circuit near the melting point to be determined. With the mounting finally adopted no such effect was observed.

Calibration of Thermocouples.-Five thermocouples were used in this determination of the melting point of palladium, designated as $P_{1}, P_{2}, S_{2}, W_{1}$, and $W_{3}$, respectively, the letters indicating the classification and use of the couples in the laboratory as primary, secondary, and working standards. The nature and source of the couples 
are given in Table XVII. The five thermocouples form a part of the set of sixteen standard platinum couples of the Bureau, all of which have been frequently intercompared and which define the temperature scale of the Bureau in the range $500^{\circ}$ to $\mathrm{I} 200^{\circ} \mathrm{C}$.

The couples were calibrated at the freezing points of pure zinc $\left(419^{\circ}\right)$, antimony $\left(630^{\circ} .5\right)$, and copper $\left(1084^{\circ}\right)$ in a reducing atmosphere). ${ }^{20}$ The metals were contained in graphite crucibles, $16.5 \mathrm{cms}$ high and about 200 ccms capacity, thus insuring ample depth of immersion. The surface of the metal was covered with powdered graphite to prevent oxidation. The calibrations were carried out in both gas and electric furnaces, and at the beginning and after the conclusion of this work. For this purpose chemically pure zinc and copper from Kahlbaum, Eimer and Amend, and Baker and Adamson were used. The freezing points of these two metals from the different sources agreed to within 0.2 . The antimony used was "Kahlbanm" antimony.

The couples were further checked during their use by determinations of the melting points of gold and silver by the wire method. Thirty-two such determinations on gold, the average value of which was $1064^{\circ} \circ$ and five on silver which gave $953^{\circ} \cdot 4$, showed that the couples remained constant to within two or three tenths of a degree, notwithstanding that small lengths of the wire at the junction were frequently cut off. 'This indicates that the wires were homogenous and that the exposures to over $\mathrm{I}_{500^{\circ}}$ in air produced no measurable clianges.

Before calibration the wires of the couples were explored for homogeneity by passing them step by step through a short electric furnace made of small bore porcelain tubing, the wires being in circuit with a sensitive D'Arsonval galvanometer. The wires were thoroughly annealed electrically at white heat previous to calibration. ${ }^{21}$ In all neasurements with thermocouples the cold junctions were kept at $\mathrm{O}^{\circ} \mathrm{C}$.

Two of the couples used in this investigation were recently calibrated at the Physikalisch-Technische Reichsanstalt and another about four years ago. These conples were also compared in an

\footnotetext{
${ }^{20}$ Holborn and Day, A11. J1. Sci., (4), 10, p. 17I; I 900.

${ }^{21}$ the results obtained at the Bureau during the past three years on the treatment and homogeneity of wires for thermoelectric nse will be published later.
} 
electric furnace with a couple calibrated at the National Physical Laboratory of England. These calibrations agree with our own to within $2^{\circ}$ at $\mathrm{I} 500^{\circ}$ ?

Potentiometer.-The measurements of the electromotive force of the thermocouples were made with a Leeds and Northrup type $\mathrm{K}$ potentiometer, modified by the addition of two shunts, so that the range was extended from I.6 to $0.00000 \mathrm{I}$ volt. As one division of the bridge wire, which consists of Io turns of manganin wire wound on a grooved marble cylinder about $5 \mathrm{~cm}$ diameter, corresponds to a length of about $2.75 \mathrm{mms}$ on the divided circular scale, estimates to within one-tenth of a microvolt can easily be made. A twentystep dial enabled the working current (0.02000 amp) to be adjusted to any value of the Weston (unsaturated) cadmium cell (I.or8o to I.Or99 volts). The potentiometer was calibrated by the electrical division of the Bureau immediately after the potentiometer was received from the makers and again during the progress of this investigation.

All measurements were referred to two Weston cadmium cells, one used as a working standard, the other as an occasional reference standard, these cells being frequently compared with the standard Clark cells of this Bureau.

Reduction of observations.-As an illustration of the method of reduction of the observations we may take the determinations in the vertical furnace with couple $W_{3}$. The calibration of $W_{3}$ is given by the following data:

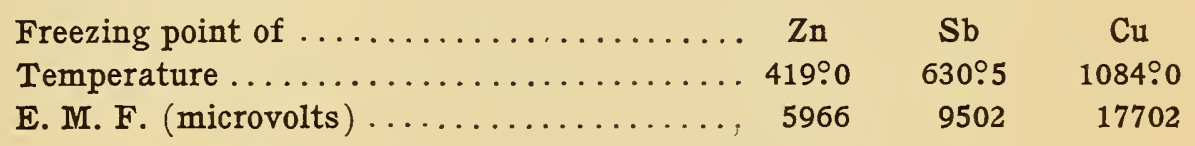

This leads to the equation:

$$
E=-498.3+\mathrm{I} 4.569 t+0.0020490 t^{2}
$$

where $E$ is expressed in microvolts and $t$ in degrees centigrade, if the cold junction is at $\mathrm{O}^{\circ} \mathrm{C}$. 
The observations at the melting point of palladium were as follows :

\begin{tabular}{|c|c|c|}
\hline \multicolumn{2}{|c|}{$\begin{array}{c}E . M . F \\
(\text { microvolts })\end{array}$} & Deviation \\
\hline & 26602 & -15 \\
\hline & 611 & -28 \\
\hline & 575 & +08 \\
\hline & 580 & +03 \\
\hline & 540 & +43 \\
\hline & 590 & -07 \\
\hline Mean $=2$ & 26583 & 17 \\
\hline Potentiometer correction $=$ & +8 & \\
\hline & 26591 & \\
\hline
\end{tabular}

By substitution in the above equation, the melting point of palladiun $=\mathrm{I} 53^{\circ}$. I, as given by $W_{3}$.

Results. - The results of the thermoelectric determination of the melting point of palladium are given in Table XVI.

TABLE XVI.

Melting Point of Palladium-Wire Method.

\begin{tabular}{|c|c|c|c|}
\hline Thermocouple & $\begin{array}{l}\text { Number of } \\
\text { Observations }\end{array}$ & $\begin{array}{l}\text { Melting Point } \\
\text { of Palladium }\end{array}$ & Remarks \\
\hline $\mathrm{w}_{1}$ & 5 & $1531: 0$ & Horizontal furnace; bare wires. \\
\hline $\mathrm{S}_{2}$ & 6 & 1530.5 & Horizontal furnace; porcelain tubes. \\
\hline $\mathrm{w}_{3}$ & 4 & 1530.0 & " \\
\hline $\mathrm{P}_{2}$ & 5 & 1529.5 & " \\
\hline$P_{1}$ & 2 & 1530.0 & Vertical furnace; see Fig. 9. \\
\hline$S_{2}$ & 2 & 1530.5 & " \\
\hline $\mathrm{P}_{2}$ & 2 & 1530.0 & “ \\
\hline $\mathrm{w}_{1}$ & 3 & 1530.5 & “ \\
\hline $\mathrm{W}_{3}$ & 6 & 1530.1 & “ \\
\hline & \multicolumn{2}{|c|}{ Mean $=1530: 2$} & \\
\hline
\end{tabular}

'The average deviation of a single observation of the melting point from the mean is $\mathrm{I}: 2$ in the thirty-five determinations here summarized, and is considerably less for the later deterninations, i. e., when the monnting of Fig. 9 was used. Some months later, additional 
determinations were carried out in the iridium furnace (p. I84), which was heated by an alternating current and in which the couples were insulated with fused magnesia tubes. These later measurements, which are entitled to less weight, gave $1528^{\circ}$. Observations with the three samples of palladium used can not be distinguished from one another.

Platinum.-Each of the optical determinations of the melting point of platinum carried out in the iridium furnace was accompanied by a thermoelectric determination. For the couples in which one wire was pure platinum, the E. M. F. was observed at the instant the platinum wire melted. For couples $W_{8}$ and $W_{9}$, which were each made of a Io per cent and of a 20 per cent alloy of rhodium with platinum, the wire method already described (p. I94) was used. For the experiments with the iridium, iridium-ruthenium couples an indicator circuit, consisting of two platinum-rhodium wires joined by a short connecting link of pure platinum placed very near the junction of the thermocouple, served to define the instant of melting of the platinum by the interruption of an electric circuit. The results are summarized in Table XVII. From two to five melts were made with each couple.

The equations in the table are those given by a calibration made after the melting point determinations. Some of the couples were also calibrated before the determinations and the equation (a) computed (see p. 20I). The melting points given in the table by equation (a) are obtained by assigning greater weight (3:I) to the final calibration.

The two series of calibrations gave the following differences in E. M. F. at $1000^{\circ}$ :

\begin{tabular}{c|c|c|c|c|c}
\hline \multirow{2}{*}{ Couple } & \multicolumn{3}{|c|}{ Platinum-Rhodium } & \multicolumn{2}{c}{ Platinum-Iridium } \\
\cline { 2 - 5 } & $\mathrm{P}_{2}$ & $\mathrm{P}_{3}$ & $\mathrm{~S}_{\mathrm{x}}$ & $\mathrm{W}_{6}$ & $\mathrm{~W}_{3}$ \\
\hline $\mathbf{E}_{\mathrm{new}}-\mathbf{E}_{\text {old }}$ Microvolts & -7 & -5 & --46 & +3 & +53 \\
\hline
\end{tabular}

The effect of exposure to very high temperature is in general to produce a decrease in E. M. F. for a given temperature, due to distillation of the rhodium and iridium. The opposite effect in the iridium couples $\left(W_{6}\right.$ and $W_{3}$ ), as well as the large effect in $S_{1}$, is 
probably due to the inhomogeneity of the wires. After each melt a short piece of wire was cut off, so that a different junction was calibrated.

\section{TABLE XVII.}

Melting Points of Palladium and Platinum by Thermoelectric Method.

\begin{tabular}{|c|c|c|c|c|}
\hline Couple & $\begin{array}{l}\text { Calibration } \\
\text { Points }\end{array}$ & Equation & $\begin{array}{l}\text { Melt- } \\
\text { ing } \\
\text { Point } \\
\text { of } \\
\text { Palla- } \\
\text { dium }\end{array}$ & $\begin{array}{l}\text { Melting } \\
\text { Point } \\
\text { of } \\
\text { Plati- } \\
\text { num }\end{array}$ \\
\hline \multirow{3}{*}{ 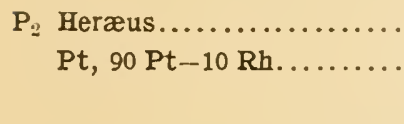 } & $\mathrm{Zn}, \mathrm{Sb}, \mathrm{Cu} .$. & $E=-266+7.991 t+0.001747 t^{2} \ldots \ldots$ & $1521^{\circ}$ & $1701^{\circ}$ \\
\hline & $\mathrm{Zn},-, \mathrm{Cu}$. & $\mathrm{E}=2.658 \mathrm{t}^{1} .184 \ldots \ldots \ldots \ldots \ldots \ldots$ & 1548 & 1745 \\
\hline & $-, \mathrm{Sb}, \mathrm{Cu} .$. & $\mathrm{E}=2,464 \mathrm{t} 1.195 \ldots \ldots \ldots$ & 1542 & 1738 \\
\hline \multirow{3}{*}{$\begin{array}{l}\mathrm{P}_{3} \text { Heræus } \ldots \ldots \ldots \ldots \ldots \ldots \\
\quad \mathrm{Pt}, 90 \mathrm{Pt}-10 \mathrm{Rh} \ldots \ldots \ldots \ldots\end{array}$} & $\mathrm{Zn}, \mathrm{Sb}, \mathrm{Cu}$. & $\mathbf{E}=-299+8.088 \mathrm{t}+0.001699 \mathbf{t}^{2}$ & 1537 & 1715 \\
\hline & $\mathrm{Zn},-, \mathrm{Cu}$ & $\mathrm{E}=2.618 \mathrm{t}^{1.187} \ldots \ldots \ldots \ldots \ldots$ & 1560 & 1753 \\
\hline & $-, \mathrm{Sb}, \mathrm{Cu}$. & $\mathrm{E}=2.460 \mathrm{t}^{1.196} \ldots$ & 1556 & 1748 \\
\hline \multirow{3}{*}{$\begin{array}{ll}\mathrm{S}_{1} & \text { Heræus } \ldots \ldots \ldots \ldots \ldots \ldots \\
& \mathrm{Pt}, 90 \mathrm{Pt}-10 \mathrm{Rh} \ldots \ldots \ldots \ldots\end{array}$} & $\mathrm{Zn}, \mathrm{Sb}, \mathrm{Cu}$. & $\mathrm{E}=-272+8.085 \mathrm{t}+0.001620 \mathrm{t}^{2} \ldots$ & 1532 & 1708 \\
\hline & $\mathrm{Zn},-, \mathrm{Cu} \ldots$ & $\mathbf{E}=2.807 \mathrm{t}^{1.176} \ldots \ldots \ldots \ldots \ldots$ & 1561 & 1754 \\
\hline & $-, \mathrm{Sb}, \mathrm{Cu} \ldots$ & $E=2.634 t^{1.185} \ldots \ldots \ldots \ldots$ & 1558 & 1747 \\
\hline \multirow{3}{*}{$\begin{array}{l}\mathrm{P}_{4} \text { Johnson and Matthey...... } \\
\text { Pt, } 90 \mathrm{Pt}-10 \mathrm{Rh} . \ldots . . .\end{array}$} & $\mathrm{Zn}, \mathrm{Sb}, \mathrm{Cu} .$. & $E=-480+9.868 t+0.001617 t^{2} \ldots \ldots$ & 1524 & 1698 \\
\hline & $\mathrm{Zn},-, \mathrm{Cu} .$. & $\mathrm{E}=3.115 \mathrm{t}^{1.183} \ldots \ldots \ldots \ldots \ldots \ldots$ & 1536 & 1717 \\
\hline & $-, \mathrm{Sb}, \mathrm{Cu} \ldots$ & $\mathrm{E}=3.115 \mathrm{t}^{1} .183 \ldots \ldots \ldots \ldots \ldots \ldots$ & 1536 & 1717 \\
\hline \multirow{3}{*}{ 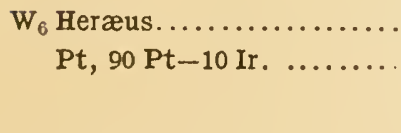 } & $\mathrm{Zn}, \mathrm{Sb}, \mathrm{Cu} \ldots$ & $E=-565+16.207 t+0.0001301 t^{2}$. & 1525 & 1710 \\
\hline & $\mathrm{Zn},-, \mathrm{Cu} \ldots \ldots$ & $E=10.210 t^{1.063} \ldots \ldots \ldots \ldots \ldots$ & 1516 & 1697 \\
\hline & $-, \mathrm{Sb}, \mathrm{Cu} \ldots$ & $E=10.967 t^{1.053} \ldots \ldots \ldots \ldots \ldots \ldots$ & 1522 & 1704 \\
\hline \multirow{3}{*}{$\begin{array}{l}\mathrm{W}_{3} \text { Carpentier } \ldots \ldots \ldots \ldots \ldots \\
\quad \mathrm{Pt}, 90 \mathrm{Pt}-10 \mathrm{Ir} . \ldots \ldots \ldots\end{array}$} & $\mathrm{Zn}, \mathrm{Sb}, \mathrm{Cu} \ldots$ & $E=-538+14.80 t+0.001911 t^{2} \ldots \ldots$ & 1528 & 1705 \\
\hline & $\mathrm{Zn},-, \mathrm{Cu} \ldots$ & $\mathrm{E}=6.095 \mathrm{t}^{1.141} \ldots \ldots \ldots \ldots \ldots \ldots \ldots$ & 1541 & 1728 \\
\hline & $-, \mathrm{Sb}, \mathrm{Cu} \ldots .$. & $\mathrm{E}=6.006 \mathrm{t} 1.143 \ldots \ldots \ldots \ldots \ldots$ & 1541 & 1728 \\
\hline \multirow{3}{*}{$\begin{array}{l}\mathrm{W}_{8} \text { Heræus } \ldots \ldots \ldots \ldots \ldots \ldots \\
\quad 90 \mathrm{Pt}-10 \mathrm{Rh}, 80 \mathrm{Pt}-20 \mathrm{Rh}\end{array}$} & $\mathrm{Zn}, \mathrm{Sb}, \mathrm{Cu} \ldots \ldots$ & $E=-170+0.2125 t+0.002031 t^{2}$. & 1507 & 1687 \\
\hline & $800^{\circ}, 1000^{\circ}, 1200^{\circ}$ & $\mathrm{E}=-800+1.525 \mathrm{t}+0.001375 \mathrm{t}^{2} \ldots \ldots$ & 1531 & 1734 \\
\hline & $800^{\circ},-, 1200^{\circ}$ & $\mathrm{E}=0.001266 \mathrm{t}^{2} .071 \ldots \ldots \ldots \ldots \ldots \ldots$ & 1497 & 1671 \\
\hline \multirow{3}{*}{$\begin{array}{l}\mathrm{W}_{0} \text { Heræus................... } \\
\quad 90 \mathrm{Pt}-10 \mathrm{Rh}, 80 \mathrm{Pt}-20 \mathrm{Rh}\end{array}$} & $\mathrm{Zn}, \mathrm{Sb}, \mathrm{Cu} \ldots \ldots$ & $E=-182+0.2850 t+0.001925 t^{2} \ldots \ldots$ & 1507 & 1710 \\
\hline & $800^{\circ}, 1000^{\circ}, 1200^{\circ}$ & $\mathrm{E}=-758+1.485 \mathrm{t}+0.001325 \mathrm{t}^{2} \ldots \ldots$ & 1530 & 1755 \\
\hline & $800^{\circ},-1200^{\circ}$ & $\mathbf{E}=0.001448 \mathrm{t}^{2.048} \ldots \ldots \ldots \ldots \ldots$ & 1498 & 1693 \\
\hline \multirow{3}{*}{ 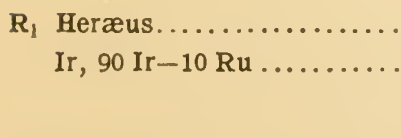 } & $600^{\circ}, 900^{\circ}, 1200^{\circ}$. & $\mathrm{E}=+308+3.312 \mathrm{t}-0.000050 \mathrm{t}^{2} \ldots \ldots$ & 1551 & 1738 \\
\hline & $600^{\circ},-, 1200^{\circ}$. & $E=7.836 t^{0.8867} \ldots \ldots \ldots \ldots \ldots \ldots$ & 1565 & 1757 \\
\hline & $600^{\circ},-, 1200^{\circ}$. & $\mathrm{E}=+344+3.222 \mathrm{t} \ldots \ldots \ldots \ldots \ldots \ldots$ & 1547 & 1726 \\
\hline \multirow{3}{*}{ 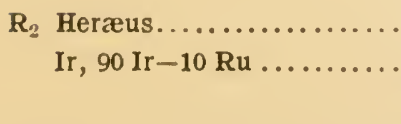 } & $600^{\circ}, 900^{\circ}, 1200^{\circ}$. & $E=-223+3.486 t-0.000072 t^{2} \ldots$ & 1533 & $(1704) ?$ \\
\hline & $600^{\circ},-, 1200^{\circ}$. & $\mathrm{E}=1.997 \mathrm{t}^{1.066} \ldots \ldots \ldots \ldots \ldots \ldots$ & 1517 & $(1676) ?$ \\
\hline & $600^{\circ},-1200^{\circ}$. & $\mathbf{E}=-172+3.358 \mathrm{t} \ldots \ldots$ & 1526 & $(1690) ?$ \\
\hline
\end{tabular}


The two formulæ most frequently used to express the relation between temperature and electromotive force for the usual platinumrhodium, and platinum-iridium thermocouples, are

(a) $E=a+b t+c t^{2}$ (Avenarius)

(b) $E=m t^{\mathrm{n}} \quad$ (Holman)

where $t$ is the temperature of the hot junction, and the cold junctions are at 0 ?

The melting points of platinum and palladium have been computed (Table XVII) by both types of equation, and for the iridium, iridium-ruthenium couples a linear extrapolation is also given.

It will at once be seen that widely different results are obtained, depending on the type of equation and the calibration data used, although within the range $400^{\circ}$ to $\mathrm{IIOO}^{\circ}$ these two equations differ nowhere by more than about $2^{\circ}$ for the usual ro per cent rhodium or iridium couples. For the couples $W_{8}$ and $W_{9}$ the curvature is so great that the values obtained by equations (a) and (b) differ greatly even within the calibrated interval.

The mean values for the melting points of palladium and platinum, as given by the Io per cent rhodium and iridium couples $P_{1}, P_{2}, P_{3}$, $P_{4}, S_{1}, S_{2}, W_{1}, W_{6}, W_{3}$, are as follows:

\begin{tabular}{|c|c|c|c|}
\hline \multirow{2}{*}{ Metal } & \multirow{2}{*}{$\begin{array}{l}\text { Equation (a) } \\
\mathrm{Zn}, \mathrm{Sb}, \mathrm{Cu}\end{array}$} & \multicolumn{2}{|c|}{ Equation (b) } \\
\hline & & $Z_{\mathrm{n}}, \mathrm{Cu}$ & $\mathrm{Sb}, \mathrm{Cu}$ \\
\hline Palladium & $1530^{\circ}$ & $1544^{\circ}$ & $1542^{\circ}$ \\
\hline Platinum . & $1706^{\circ}$ & $1732^{\circ}$ & $1730^{\circ}$ \\
\hline
\end{tabular}

The values obtained for the melting points of palladium and platinum by the application of equation (a) to the thermocouple observations are considerably lower than the values obtained by the optical observations and Wien's equation. For the ro per cent rhodium and iridium couples, equation (b) gives values which are much closer to the optical values. If by the "true temperature" we mean the temperature by the thermodynamic or ideal gas scale, Wien's equation, with the constant $c_{2}$ determined from observations within the range of practical gas thermometry, gives at present the closest convenient representation of the true temperature. 


\section{GENERAL DISCUSSION AND CONCLUSIONS.}

The precautions necessary in the construction and use of an experimental black-body to give ideal black-body radiation have been described at length. It was possible to construct a black-body in which the temperature distribution at $\mathrm{I} 300^{\circ}$ was constant to $\mathrm{I}^{\circ}$ throughout the greater part of the radiating inclosure.

Five pyrometer lamps were calibrated by comparison with thermocouples up to $I 300^{\circ}$, using this uniformly heated black-body as radiating source. The relation between the black-body temperature and the current through the lamps is represented by an equation of the form $I=a+b t+c t^{2}$, with an average deviation of less than $I: 5$.

In order to extend the optical scale to higher temperatures, the absorption coefficients of absorbing mirrors and glasses were determined for red and green light. The effect of lack of monochromatism of so-called monochromatic glasses on temperature measurements was investigated, as well as the effect of the polarization of light emitted by palladium and platinum on the absorption coefficient of the mirrors.

The relation of the radiation of palladium and platinum to that of a black-body was investigated, experimentally, for red and green light, up to I250: Three methods of estimating the actual temperature of the radiating surface were used.

Table XVIII gives the results obtained where

$t=$ true temperature of the radiating surface, and

$s=$ corresponding black-body temperature.

TABLE XVIII.

Radiation from Platinum and Palladium.

\begin{tabular}{|c|c|c|c|c|c|c|c|c|c|}
\hline s & $700^{\circ}$ & $800^{\circ}$ & $900^{\circ}$ & $1000^{\circ}$ & $1100^{\circ}$ & $1200^{\circ}$ & $1300^{\circ}$ & $1400^{\circ}$ & $1500^{\circ}$ \\
\hline \multicolumn{10}{|c|}{ PLATINUM. } \\
\hline $\begin{array}{c}t-s \\
(\lambda=0.66 \mu)\end{array}$ & 46 & 58 & 72 & 90 & 110 & 132 & 155 & (178) & (200) \\
\hline $\begin{array}{c}t-s \\
(\lambda=0.55 \mu)\end{array}$ & & & 53 & 68 & 86 & 103 & 121 & (139) & (157) \\
\hline
\end{tabular}

PALLADIUM.

\begin{tabular}{l|ll|l|l|l|l|l|l|l}
$\begin{array}{c}\mathrm{t}-\mathrm{s} \\
(\lambda-0.66 \mu)\end{array}$ & 1 & 46 & 58 & 72 & 90 & 110 & 129 & (143) & $\ldots \ldots \ldots \ldots \ldots$ \\
\hline
\end{tabular}


The melting points of palladium and platinum were measured by three methods:

(I) The black-body method in which the temperature of melting within an electrically heated iridium furnace was measured with an optical pyrometer.

(2) The surface-radiation method in which the black-body temperature of electrically heated ribbons of these metals was measured at the instant of melting.

(3) The thermoelectric method based on extrapolation by several formulæ. Ten thermocouples of the following types were used: Pt, $90 \mathrm{Pt-Io} \mathrm{Rh;} \mathrm{Pt,} 90 \mathrm{Pt}$-Io Ir; $90 \mathrm{Pt-Io} \mathrm{Rh,} \mathrm{80} \mathrm{Pt-20} \mathrm{Rh;} \mathrm{Ir,}$ 90 Ir-Io Ru.

The results of the experiments by the black-body method are summarized in Table XIX, where

$$
\begin{aligned}
& t_{1}=T_{1}-273^{\circ}=\text { observed black-body temperature, } \\
& K=\text { absorption coefficient of the screen used, } \\
& \lambda=\text { wave length of light, } \\
& c_{2}=\text { constant of the equation, } \log K=\frac{c_{2} \log e}{\lambda}\left(\frac{I}{T_{1}}-\frac{\mathrm{I}}{T_{2}}\right)
\end{aligned}
$$

$$
t_{2}=T_{2}-273^{\circ}=\text { calculated temperature }{ }^{\circ} \mathrm{C} \text {. of melting point. }
$$

The highest temperatures measured with the sector disk were $1242^{\circ}$ in the experiments with red, and $1365^{\circ}$ in experiments with blue light. At these temperatures, the scale defined by the pyrometer lamps, which is here practically in agreement with the extrapolated thermoelectric scale, is certainly not much in error; while the temperatures measured by the absorbing mirrors, $1080^{\circ}$ for the red and II $55^{\circ}$ for the green, are within the range of known temperatures; and the results obtained by the use of mirrors are in most satisfactory agreement with those obtained with the sector disk.

The surface radiation method, which is not capable of the same order of accuracy as the preceding, and which is regarded only as corroborative, gives for the melting point of platinum $175^{\circ}$, and for palladium $r 563^{\circ}$ on the basis of a linear extrapolation of the relation between $s^{\circ}$ and $t^{\circ}-s^{\circ}$. On account of the changes in the surface of palladium at high temperatures, this method gives a 
higher value for that metal than the black-body method, as is to be expected.

TABLE XIX.

Melting Points by Black-body Method.

PLATINUM.

\begin{tabular}{|c|c|c|c|c|c|c|c|c|}
\hline Group & $\begin{array}{c}t_{1} \\
\text { obs. }\end{array}$ & $\begin{array}{c}\mathrm{t}_{2} \\
\text { comp. }\end{array}$ & $\mathrm{K}$ & $\lambda$ & $c_{2}$ & $\begin{array}{l}\text { No. } \\
\text { of } \\
\text { obs. }\end{array}$ & Remarks & $\begin{array}{l}\text { Melt- } \\
\text { ing } \\
\text { Point }\end{array}$ \\
\hline a & $1242^{\circ}$ & $1745^{\circ}$ & 35.5 & 0.668 & 14500 & 10 & $\left\{\begin{array}{c}\text { Sector disk and Wein's } \\
\text { equation }\end{array}\right.$ & \\
\hline b & 1310 & 1740 & " & .547 & "6 & 6 & “ & \\
\hline c & 1365 & 1741 & " & .462 & " & 4 & “ & $1745^{\circ}$ \\
\hline d & 1080 & 1746 & 199 & .668 & " & 16 & $\left\{\begin{array}{c}\text { Absorbing mirrors and } \\
\text { Wien's equation }\end{array}\right.$ & \\
\hline e & 1155 & 1744 & 228 & .547 & " & 7 & " $"$ " & \\
\hline
\end{tabular}

PALLADIUM.

\begin{tabular}{|c|c|c|c|c|c|c|c|c|}
\hline$a^{1}$ & $985^{\circ}$ & $1540^{\circ}$ & 200 & 0.666 & 14500 & 8 & $\left\{\begin{array}{c}\text { Absorbing mirrors and } \\
\text { Wein's equation }\end{array}\right.$ & \\
\hline$b^{1}$ & 984.5 & 1539 & " & " & " & 7 & " 6 & \\
\hline$c^{l}$ & 1124.5 & 1540 & 35.5 & “ & " & 11 & $\left\{\begin{array}{c}\text { Sector disk and Wein's } \\
\text { equation }\end{array}\right.$ & $1540^{\circ}$ \\
\hline$d^{\prime}$ & 1547 & -9 & 1 & " & & 7 & $\left\{\begin{array}{c}\text { Lamp equation extra- } \\
\text { polation }\end{array}\right.$ & \\
\hline
\end{tabular}

The temperatures estimated by thermoelectric extrapolation differ very considerably depending upon the formula and calibration data used. The two types of formula

(a) $E=a+b t+c t^{2}$

(b) $\quad E=m t^{\mathrm{n}}$

which agree to within $2^{\circ}$ up to $1200^{\circ}$ for the usual ro per cent platinum-rhodium and platinum-iridium thermocouples, were compared at the melting points of palladinm and platinum, for the four types of couple mentioned above. The usual ro per cent platinumrhodium and platinum-iridium thermocouples give, by formula (a), $\mathrm{I} 530^{\circ}$ and $\mathrm{I} 706^{\circ}$, and by formula (b), $\mathrm{I} 543^{\circ}$ and $\mathrm{I} 73 \mathrm{I}^{\circ}$, for the melting points of palladium and platinum, respectively. The other types 
of thermocouples give results differing $25^{\circ}$ or more from these values. Harker ${ }^{22}$ using formula (a) and several types of thermocouples found $17 \mathrm{IO}^{\circ}$ for platinum. Holborn and Henning ${ }^{23}$ have published the values $1535^{\circ}$ and $1710^{\circ}$ for the melting points of palladium and platinum, presumably by this same method. The temperature scale obtained by extrapolation based on the use of formula (a) and the usual ro per cent platinum-rhodium and platinum-iridium thermocouples, differs from the optical scale resulting from this investigation by the amounts given in Table XX.

\section{TABLE XX.}

Thermoelectric and Optical Scales.

\begin{tabular}{|c|c|c|c|c|c|c|}
\hline $\begin{array}{c}\text { Temperatures on Thermoelectric } \\
\text { Scale }\end{array}$ & $1200^{\circ}$ & $1300^{\circ}$ & $1400^{\circ}$ & $1500^{\circ}$ & $1600^{\circ}$ & $1700^{\circ}$ \\
\hline Optical-Thermoelectric. & 0 & 2 & 6 & 14 & 25 & 43 \\
\hline
\end{tabular}

Nernst and Wartenberg ${ }^{24}$ using the black-body method and a Wanner optical pyrometer adjusted for yellow light, found for palladium $\mathrm{I} 54 \mathrm{I}^{\circ}$ and for platinum $\mathrm{I} 745^{\circ}$, where the constant of the Wien equation was taken as $\mathrm{c}_{2}=\mathrm{I} 460 \mathrm{O}$, and the melting point of gold as 1064. On the basis of $c_{2}=14500$, as used in the present investigation, Nernst and Wartenberg's values become $\mathrm{I} 545^{\circ}$ for palladium and $170^{\circ}$ for platinum.

Since the completion of the experiments described in this paper, Holborn and Valentiner, ${ }^{25}$ in an elaborate intercomparison of the optical temperature scale with the scale of the gas thermometer to $\mathrm{I} 600^{\circ}$, have found for the constant of the Wien equation, $\mathrm{c}_{2}=\mathrm{I} 4200$, and for the melting points of palladium and platinum, $1582^{\circ}$ and I7 $89^{\circ}$, respectively.

The generally accepted value, $c_{2}=14500$, used in the present investigation, is that based on the experiments of Lummer and Pringsheim, of Paschen, and of Wanner. It becomes of interest to discuss the effect on the results of the present investigation of changing the value of $c_{2}$. We have therefore in Table XXI given

${ }^{22}$ Harker, Chemical News, 91, p. 262; 1905.

${ }^{23}$ Holborn and Henning, Sitzber. Berlin Akad., 12, p. 33I; 1905.

${ }^{24}$ Nernst and Wartenberg, Verh. Deutsch Phys. Ges., 8, p. 48; 1906.

${ }^{25}$ Holborn and Valentiner, Ann. der Physik., 22, p. I; I907. 
these results recomputed on the basis of $c_{2}=I_{4} 600$ and $c_{2}=I_{4} 200$ and also the effect of expressing the observed temperatures $\left(t_{1}\right)$ on the Holborn-Valentiner gas scale. The key to the table is the same as for Table XIX. The letters a, b, c, etc., under column headed "Group" refer to observations in the corresponding line of Table XIX.

\section{TABLE XXI.}

Melting Points of Platinum and Palladium Reduced by Several Methods. PLATINUM.

\begin{tabular}{|c|c|c|c|c|c|c|c|c|}
\hline Group & $\begin{array}{c}\mathrm{t}_{1} \\
\text { obs. }\end{array}$ & comp. & $\mathrm{K}$ & r & $\mathrm{c}_{2}$ & Remarks & \multicolumn{2}{|c|}{$\begin{array}{l}\text { Melting } \\
\text { points } \\
\text { (comp.) }\end{array}$} \\
\hline a & $1242^{\circ}$ & $1740^{\circ}$ & 35.5 & 0.663 & 14600 & $\left\{\begin{array}{c}\text { Groups b-e give same } \\
\text { Melting Point as Group } \\
\text { a. Value of c. used br }\end{array}\right.$ & $1740^{\circ}$ & $I$ \\
\hline & & & & & & $\begin{array}{l}\text { Nernst and Warten- } \\
\text { berg..................... }\end{array}$ & & \\
\hline a & 1242 & 1759 & " & .668 & 14200 & $\left\{\begin{array}{c}\text { Value of } c_{2} \text { found by Hol- } \\
\text { born and Valentiner.... }\end{array}\right.$ & & \\
\hline b & 1310 & 1750 & " & .547 & " & " $\quad$ w $\quad$ w $\ldots \ldots$ & 1756 & II \\
\hline c & 1365 & 1750 & “ & .462 & " & 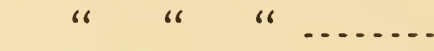 & & \\
\hline a & 1246 & 1766 & " & .668 & "6 & $\left\{\begin{array}{r}t_{1} \text { expressed on H.-V.gas } \\
\text { scale } \ldots \ldots \ldots\end{array}\right.$ & & \\
\hline $\mathrm{b}$ & 1319 & 1765 & “6 & .547 & " & u $\quad$ w $\quad$ w $\ldots \ldots$ & 1766 & III \\
\hline c & 1377 & 1768 & “ & .462 & “ & " & & \\
\hline d & 1080 & 1760 & 192 & .668 & “ & $\left\{\begin{array}{r}\mathrm{K} \text { computed on } \mathrm{H} . \mathrm{V} \text {. gas } \\
\text { scale } \ldots \ldots \ldots \ldots \ldots\end{array}\right.$ & 1758 & IV \\
\hline e & 1155 & 1757 & 219 & .547 & “ & " $\quad$ & & \\
\hline $\mathrm{d}$ & 1080 & 1748 & 179 & .668 & “ & $\mathrm{K}$ computed for $\mathrm{c}_{2}=14200$ & & V \\
\hline e & 1155 & 1743 & 201 & .547 & “ & " " “ & $1 / 40$ & $v$ \\
\hline
\end{tabular}

\section{PALLADIUM.}

\begin{tabular}{|c|c|c|c|c|c|c|c|c|}
\hline$c^{1}$ & $1124: 5$ & $1536^{\circ}$ & 35.5 & 0.666 & 14600 & $\left\{\begin{array}{r}\text { Value of } c_{2} \text { used by Nernst } \\
\text { and Wartenberg ....... }\end{array}\right.$ & $1536^{\circ}$ & $\mathrm{I}^{1}$ \\
\hline$c^{1}$ & 1124.5 & 1551 & .. & .. & 14200 & $\left\{\begin{array}{c}\text { Value of } c_{2} \text { found by Hol- } \\
\text { born and Valentiner... }\end{array}\right.$ & 1551 & II $^{1}$ \\
\hline$a^{1}$ & 985 & 1551 & 192 & .. & .. & $\left\{\begin{array}{r}\mathrm{K} \text { computed on } \mathrm{H} . \mathrm{V} \text {. gas } \\
\text { scale } \ldots \ldots \ldots \ldots\end{array}\right.$ & \} 1551 & IV $^{1}$ \\
\hline$a^{1}$ & 985 & 1540 & 171 & .. & .. & $\mathrm{K}$ computed for $c_{2}=14200$. & 1540 & $\mathrm{~V}^{1}$ \\
\hline
\end{tabular}


From Table XXI $\left(I\right.$ and $\left.I^{1}\right)$ it will be seen that the observations when reduced for $c_{2}=\mathrm{I} 4600$, would give $1740^{\circ}$ for platinum and $1536^{\circ}$ for palladium. The results of the sector-disk experiments ( $I I$ and $I I^{1}$ ), when reduced for $c_{2}=\mathrm{I} 4200$, give $175^{\circ}$ and $155^{\circ}$. The same observations when the observed temperature $t_{1}$ is expressed on the Holborn-Valentiner gas scale give $(I I I)$ for platinum, I $766^{\circ}$. The value for palladium is unchanged because the observed value of $t_{1}\left(=\operatorname{II} 24^{\circ} \cdot 5\right)$ is within the range of the Holborn-Day gas scale with which the Holborn-Valentiner scale was made to coincide at this temperature.

With the absorbing mirrors, assuming $c_{2}=\mathrm{I} 42 \mathrm{OO}$ and computing $K$ (experiments on p. I72) on the Holborn-Valentiner gas scale ( $I V$ and $\left.I V^{1}\right)$, the platinum point would be $175^{\circ}$ and the palladium point $\mathrm{I} 55^{\circ} \mathrm{I}^{\circ}$ If, in the computation of $K$, temperatures are expressed on the scale defined by the pyrometer lamps and $c_{2}$ is taken as $14200\left(V\right.$ and $\left.V^{1}\right)$, the melting points would be $1746^{\circ}$ and I $540^{\circ}$, respectively.

Using $c_{2}=\mathrm{I} 4200$ and expressing the observed temperatures $t_{1}$ on the Holborn-Valentiner scale, the mean of the experiments with the mirrors and with the sector disk gives $I 762^{\circ}$ for platinum and $155^{\circ}{ }^{\circ}$ for palladium. These seem to be the maximum temperatures that can be assigned from our experiments. Furthermore, when this method of reduction is used, the observations with the sector disk and with the absorbing mirrors are not in agreement.

As a further illustration of the effects on our results of reduction by the two methods, nainely, on the one hand, using $c_{2}=14500$ and the temperature scale given by the pyrometer lamps, and, on the other hand, using $c_{2}=\mathrm{I} 4200$ and expressing temperatures on the Holborn-Valentiner scale, we have computed the absorption factor of the sector disk by both methods, as shown in Table XXII.

The observed value of $K$ is that obtained by measurements with a circular dividing engine.

The difference in $K$, as computed by the two methods, can not be accounted for by differences in $t_{1}$, as at $\mathrm{I} 250^{\circ}$ for example the two temperature scales differ by less than $5^{\circ}$, but is due to the different values assumed as the melting points of platinum and palladium. 
TABLE XXII.

Computation of Absorption Factor of Sector Disk.

\begin{tabular}{|c|c|c|c|c|c|c|c|}
\hline Group & . $t_{1}$ obs & $\begin{array}{l}t_{2} \text { as- } \\
\text { sumed }\end{array}$ & $\lambda$ & $\mathrm{c}_{2}$ & Remarks & $\begin{array}{l}\text { K com- } \\
\text { puted }\end{array}$ & $\begin{array}{l}\mathrm{K} \text { ob- } \\
\text { served }\end{array}$ \\
\hline a & $1243^{\circ}$ & $1745^{\circ}$ & 0.668 & 14500 & $\begin{array}{l}\text { Pyrometer lamp scale, Wien } \\
\text { equation } . . . . . . . . . .\end{array}$ & 35.6 & \\
\hline $\mathrm{b}$ & 1310 & 1745 & .547 & 14500 & $\begin{array}{l}\text { Pyrometer lamp scale, Wien } \\
\text { equation } . . . . . . . . . . .\end{array}$ & 36.9 & \\
\hline$c^{1}$ & 1124.5 & 1540 & .666 & 14500 & $\begin{array}{l}\text { Pyrometer lamp scale, Wien } \\
\text { equation ................ }\end{array}$ & 35.5 & \\
\hline & & ....... & $\ldots . .$. & $\ldots . .$. & $\ldots, \ldots, \ldots, \ldots,{ }_{n}$ & $\ldots$. & 35.5 \\
\hline a & 1246 & 1789 & .668 & 14200 & Holborn-Valentiner gas scale. & 38.8 & \\
\hline $\mathrm{b}$ & 1319 & 1789 & .547 & 14200 & 66 & 41.1 & \\
\hline$c^{1}$ & 1124.5 & $\begin{array}{l}1582 \\
t_{2} \mathrm{obs}\end{array}$ & .666 & $\begin{array}{l}14200 \\
-\end{array}$ & 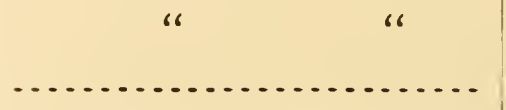 & $\begin{array}{c}43.1 \\
-\ldots .\end{array}$ & \\
\hline $\mathrm{p}-$ & 950.5 & 1253 & .660 & 14500 & $\begin{array}{l}\text { Pyrometer lamp scale, Wien } \\
\text { equation } . . . . . . . . . .\end{array}$ & 35.2 & \\
\hline 66 & 950.5 & 1257 & .660 & 14200 & $\begin{array}{l}\text { Holborn - Valentiner s c a le } \\
\text { Wien equation............ }\end{array}$ & 35.0 & \\
\hline
\end{tabular}

In view of the above discussion, the most probable values of the melting points of palladium and platinum, resulting from the experiments of this investigation, are $1540^{\circ}$ and $1745^{\circ}$, respectively, on the basis of Wien's equation. A further correction has to be applied for the lack of blackness of the iridium furnace (p. I85), so that our final values are $1546^{\circ}$ for the melting point of palladium and $1753^{\circ}$ for the melting point of platinum.

The wide fluctuations in the values of these melting points as obtained by various observers within the past two years by the use of different methods, makes further experimental work necessary. On account of the more satisfactory theoretical basis of the StefanBoltzmann law, which gives temperatures on the thermodynamic scale, it is planmed to attack the problem from this standpoint.

WASHING'TON, March 4, I907. 